\title{
Partition Coefficients of Platinum Group and Chalcophile Elements Between Arsenide and Sulfide Phases as Determined in the Beni Bousera Cr-Ni Mineralization (North Morocco)
}

\author{
Rubén Piña,,+ Fernando Gervilla, ${ }^{2}$ Sarah-Jane Barnes, ${ }^{3}$ Lorena Ortega, ${ }^{1}$ And Rosario LunaR ${ }^{1}$ \\ ${ }^{1}$ Departamento de Cristalografía y Mineralogía, Facultad de Ciencias Geológicas, Universidad Complutense de Madrid, c/ José \\ Antonio Novais s/n, 28040 Madrid, Spain \\ ${ }^{2}$ Departamento de Mineralogía y Petrología and Instituto Andaluz de Ciencias de la Tierra, Facultad de Ciencias, \\ Universidad de Granada-CSIC, Avda. Fuentenueva s/n, 18002 Granada, Spain \\ ${ }_{3}^{3}$ Sciences de la Terre, Université du Québec à Chicoutimi, 555 bld. de l'Université, Saguenay, Québec, G7H 2B1 Canada
}

\begin{abstract}
The partition coefficients of platinum group elements (PGE) and chalcophile elements Au, Re, Ag, Se, Bi, $\mathrm{Te}$, and $\mathrm{Sb}$, between arsenide and sulfide phases ( $\mathrm{D}^{\mathrm{As}} /$ sulf $)$ have been estimated by measuring in situ concentrations of these elements using laser ablation-inductively coupled plasma-mass spectrometry (LA-ICP-MS) in coexisting arsenide and sulfide minerals from the Beni Bousera $\mathrm{Cr}-\mathrm{Ni}$ mineralization (North Morocco). Previous experimental studies and observations on the distribution of PGE in a number of As-rich, Ni-Cu-PGE ore deposits have shown that arsenide minerals may play an important role controlling the distribution of these metals in magmatic sulfide systems. However to date, there is no comprehensive study quantifying the partitioning behavior of these elements when arsenide minerals crystallize either directly from a sulfide melt or from an arsenide melt previously segregated by immiscibility from a sulfide melt. The Beni Bousera mineralization represents an excellent natural laboratory to evaluate these partition coefficients because maucherite $\left(\mathrm{Ni}_{11} \mathrm{As}_{8}\right)$ coexists in equilibrium with pyrrhotite, pentlandite, and chalcopyrite in form of globules mostly associated with pyrrhotite, and arsenide and sulfide minerals account for the bulk of the PGE (with the exception of $\mathrm{Pt}$ ) and chalcophile elements in the samples. The laser ablation analyses reveal that maucherite is strongly enriched in all chalcophile elements, except Se, relative to sulfide minerals. The calculated $\mathrm{D}_{\mathrm{PGE}}{ }^{\mathrm{As} / \text { sulf }}$ are the following: $\mathrm{D}_{\mathrm{Ir}}{ }^{\mathrm{As} / \text { sulf }}=920 \mathrm{D}_{\mathrm{Rh}}{ }^{\mathrm{As} / \text { sulf }}=620, \mathrm{D}_{\mathrm{Pt}}{ }^{\mathrm{As} / \text { sulf }}=330, \mathrm{DPd}^{\mathrm{As} / \text { sulf }}=250, \mathrm{D}_{\mathrm{Os}^{\mathrm{As}} / \mathrm{sulf}}=140$, and $\mathrm{D}_{\mathrm{Ru}}{ }^{\mathrm{As} / \mathrm{sulf}}=50$. For the rest of elements, the obtained values are the following: $\mathrm{D}_{\mathrm{Sb}^{\mathrm{As}}}{ }^{\mathrm{sulf}}=890, \mathrm{D}_{\mathrm{Te}}^{\mathrm{As} / \text { sulf }}=190, \mathrm{D}_{\mathrm{Bi}} \mathrm{As}^{\mathrm{As}} / \mathrm{sulf}=$ $50, \mathrm{D}_{\mathrm{Re}}{ }^{\mathrm{As} / \text { sulf }}=6, \mathrm{D}_{\mathrm{Au}}{ }^{\mathrm{As} / \text { sulf }}=310, \mathrm{D}_{\mathrm{Ag}}{ }^{\mathrm{As} / \text { sulf }}=4$, and $\mathrm{D}_{\mathrm{Se}} \mathrm{As}^{\mathrm{As} / \text { sulf }}=0.6$. These results clearly highlight the strong affinity of PGE for arsenide phases and the importance of these phases as potential carriers of PGE in Ni-CuPGE ore deposits.
\end{abstract}

\section{Introduction}

NiCKEL-Cu magmatic sulfide deposits form by crystallization of sulfide melts segregated from silicate magmas after reaching sulfur saturation (e.g., Naldrett, 2004). During this process, platinum group elements (PGE: Os, Ir, Ru, Rh, Pd, and $\mathrm{Pt}$ ) and chalcophile elements ( $\mathrm{Ni}, \mathrm{Cu}, \mathrm{Co}, \mathrm{Ag}, \mathrm{Au}, \mathrm{Sb}, \mathrm{As}$, $\mathrm{Se}, \mathrm{Te}$, and $\mathrm{Bi}$ ) are collected by the sulfide melt due to their high partition coefficients between sulfide and silicate melts (e.g., Peach et al., 1990; Fleet et al., 1991; Crocket et al., 1992). The distribution of PGE in most magmatic sulfide deposits is mainly controlled by the distribution of base metal sulfides that crystallize from sulfide melt (pyrrhotite, pentlandite, and chalcopyrite). Platinum group elements commonly occur in solid solution within these sulfides (e.g., Barnes et al., 2006; Holwell and McDonald, 2007; Dare et al., 2010) and/or as discrete platinum group minerals (PGM, e.g., sulfides, arsenides, bismuthotellurides, and tellurides) texturally associated with them (e.g., Huminicki et al., 2005; Godel et al., 2007; Hutchinson and McDonald, 2008). However, in a number of As-rich Ni-Cu sulfide ores, PGE preferentially concentrate in the most As rich ore zones, leaving the relatively As poor, $\mathrm{S}$ rich zones typically depleted in such noble metals (e.g., Ronda and Beni Bousera ultramafic massifs, Spain and Morocco, respectively, Gervilla and Leblanc, 1990,

\footnotetext{
† Corresponding author: email, rpinagar@geo.ucm.es
}

Gervilla et al., 1996; Kylmäkoski deposit, Finland, Papunen, 1989, Gervilla et al., 1998; Dundonald Beach South deposit, Canada, Hanley, 2007; Talnotry deposit, Scotland, Power et al., 2004; Creighton deposit, Sudbury, Canada, Dare et al., 2010; Rosie Nickel prospect, Australia, Godel et al., 2012). In these cases, PGE occur either as early crystallized As-bearing PGM from a sulfide melt (e.g., sperrylite PtAs 2 , irarsite IrAsS, hollingworthite RhAsS) or dissolved in trace amounts within arsenide and/or sulfarsenide minerals (e.g., nickeline NiAs, maucherite $\mathrm{Ni}_{11} \mathrm{As}$, gersdorffite NiAsS) formed from an arsenide melt previously segregated from a sulfide melt.

In spite of the strong affinity between PGE and arsenides, little is known to date about the partition coefficients of PGE between arsenide and sulfide phases. The only experimental work carried out to quantify these partition coefficients (although only for Pd) is that of Wood (2003) who produced the segregation of arsenide and sulfide melts from an As-S-Pd-Ircontaining basaltic melt at $1,000^{\circ} \mathrm{C}$. Wood (2003) measured the $\mathrm{Pd}$ concentration in the crystallizing arsenide and sulfide minerals, obtaining a minimum $\mathrm{D}_{\mathrm{Pd}^{\mathrm{As}} \text { sulf }}$ of 33.9. More recently, Hanley (2007) and Godel et al. (2012) inferred $\mathrm{D}_{\mathrm{PGE}^{\mathrm{As}}}{ }^{\mathrm{Asulf}}$ on the order of 10 to 100 in the high-grade $\mathrm{Pd}$ and Pt sulfide mineralization of Dundonald Beach South (Canada) and 25 to 400 in the Rosie Nickel prospect (Australia), respectively.

In this study, we have calculated partition coefficients for PGE, $\mathrm{Au}$, and the chalcophile elements $\mathrm{Se}, \mathrm{Te}, \mathrm{Bi}, \mathrm{Sb}, \mathrm{Re}$, 
and $\mathrm{Ag}$, between arsenide and sulfide phases, by determining the concentration of these elements in coexisting arsenides (maucherite) and sulfides (pyrrhotite, pentlandite, and chalcopyrite) in samples from the Amasined Cr-Ni mineralization (Beni Bousera lherzolite massif, North Morocco). Because such phases account for the bulk of PGE in these samples (as indicated below by the mass-balance calculation), they represent an excellent opportunity to evaluate the magnitude of these partition coefficients.

\section{Locality Description}

The Amasined Cr-Ni mineralization refers to a small occurrence located in the northern part of the Beni Bousera lherzolite massif in Morocco (Fig. 1). This lherzolite massif forms part of the Internal zone of the Alpine Betic-Rifean chain and constitutes a portion of subcontinental lithospheric mantle emplaced at high temperature into Paleozoic metasediments during the Alpine orogeny, 20 to $22 \mathrm{Ma}$ ago (Reuber et al., 1982; Zindler et al., 1983; Tubia and Cuevas, 1986). The Beni Bousera massif is made up of three main tectono-metamorphic domains: garnet-spinel mylonites, mylonitic to porphyroclastic garnet-spinel lherzolites containing garnet pyroxenitic layers, and porphyroclastic to granular spinel lherzolites with differing amounts of spinel pyroxenitic layers (Fig. 1; Reuber et al., 1982). Country host rocks include metamorphic rocks (mostly, gneises and schists) that display decreasing metamorphic grade outward from the contact with the peridotite massif (Fig. 1). The mineralization consists of a lens of massive sulfides 20 to $30 \mathrm{~m}$ long and up to $1 \mathrm{~m}$ thick, oriented roughly parallel to the foliation of the enclosing lherzolite rocks. The ore mineralogy mostly comprises pyrrhotite $\left(\mathrm{Fe}_{1-\mathrm{x}} \mathrm{S}\right)$, pentlandite $\left[(\mathrm{Fe}, \mathrm{Ni})_{9} \mathrm{~S}_{\mathrm{S}}\right]$, chalcopyrite $\left(\mathrm{FeCuS}_{2}\right)$, chromite $\left[\left(\mathrm{Fe}^{2+}{ }_{0.7} \mathrm{Mg}_{0.3}\right)\right.$ $\left.\left(\mathrm{Cr}_{1.1} \mathrm{Al}_{0.8} \mathrm{Fe}^{3+}{ }_{0.1}\right) \mathrm{O}_{4}\right]$, and maucherite $\left(\mathrm{Ni}_{11} \mathrm{As} 8\right)$, with minor violarite $\left(\mathrm{FeNi}_{2} \mathrm{~S}_{4}\right)$, nickeline (NiAs), members of the solidsolution cobaltite-gersdorffite (CoAsS-NiAsS), westerveldite
[(Fe, Co, Ni)As], and graphite (Gervilla et al., 1996). The silicate assemblage is made up of partially chloritized phlogopite, secondary amphibole and chlorite. Sulfides comprise more than $80 \mathrm{vol} \%$ of ore, with pyrrhotite being the most abundant. Pentlandite mainly occurs as coarse-grained aggregates and minor flame-like exsolutions within pyrrhotite (Fig. 2A). Chalcopyrite is randomly distributed as anhedral grains throughout the mineralization (Fig. 2A-B). Chromite forms typically idiomorphic to subidiomorphic crystals (Fig. 2) mostly concentrated in the lower part of the orebody. Arsenides are restricted to the 5- to 8-cm-thick, basal zone situated along the footwall of the orebody. They consist mostly of radially fractured, lobular or rounded maucherite globules within pyrrhotite (Fig. 2C). In many cases, they include early-crystallized chromite crystals (Fig. 2D-E) and are located along the contact between chromite and pyrrhotite (Fig. 2F). In a few examples, thin rims of cobaltite surround the maucherite globules (Fig. 2G) and, more rarely, nickeline occurs in their cores (Fig. 2H). Westerveldite rarely occurs along maucherite cracks (Fig. 2H). Based on a number of observations such as the relatively fresh nature of the host peridotite, the sulfide assemblage, and the mantle signature of sulfur isotopes $\left(\delta^{34} \mathrm{~S}\right.$ $=1.4$ and $0.7 \%$ ), Gervilla and Leblanc (1990) and Gervilla et al. (1996) suggested a magmatic origin for the mineralization.

\section{Analytical Methods}

A total of five polished blocks were studied by optical microscope to select sites for electron microprobe and laser ablation analyses. Maucherite and sulfide minerals (pyrrhotite, pentlandite, and chalcopyrite) were then analyzed for major elements ( $\mathrm{S}, \mathrm{Fe}, \mathrm{Ni}, \mathrm{Cu}, \mathrm{Co}$, and As, Table 1) at the Electron Microscope Centre of the University Complutense of Madrid, using a JEOL JXA-8900M electron microprobe. The accelerating voltage was $20 \mathrm{kv}$, the beam current $50 \mathrm{nA}$, and the beam diameter 1 to $5 \mu \mathrm{m}$. The calibration was carried out using

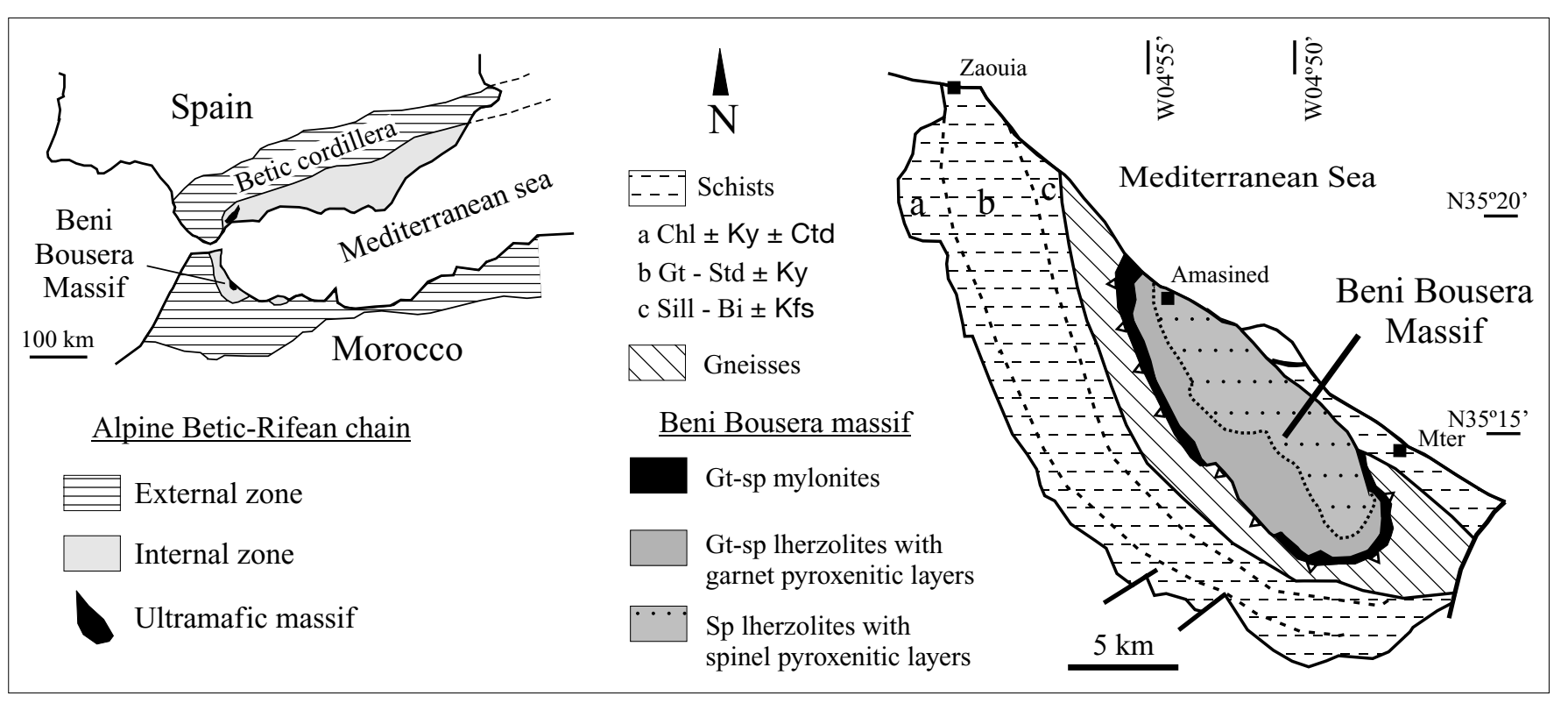

FIG. 1. Location within the Alpine Betic-Rifean chain and simplified geologic map of the Beni-Bousera lherzolite massif. Modified from Michard et al. (2006). $\mathrm{Bi}=$ biotite, $\mathrm{Chl}=$ chlorite, $\mathrm{Ctd}=$ cordierite, $\mathrm{Gt}=$ garnet, $\mathrm{Kfs}=$ alkali feldspar, $\mathrm{Ky}=$ kyanite; Sill = sillimanite, $\mathrm{Sp}=$ spinel, $\mathrm{Std}=$ staurolite . 

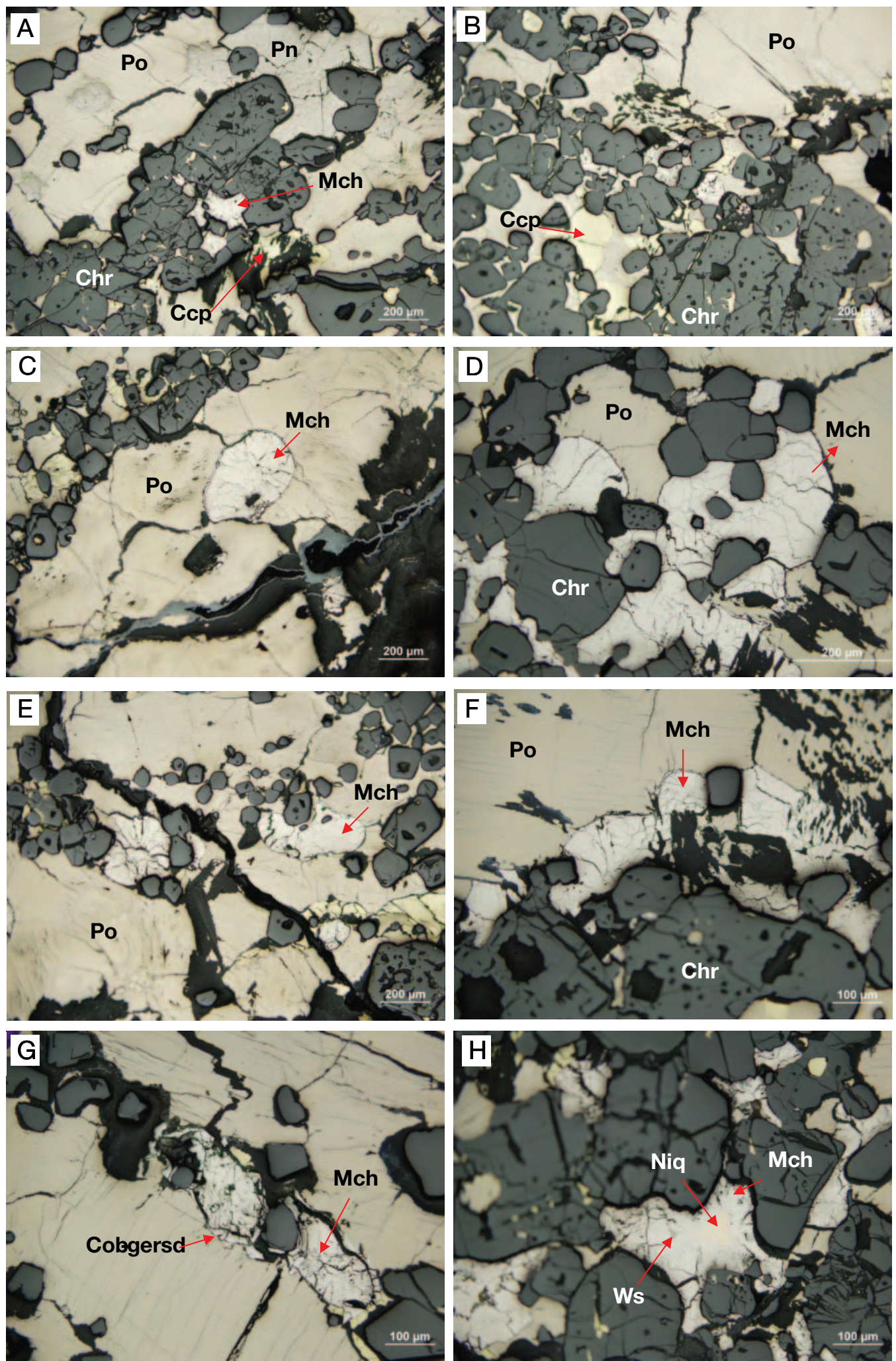

FIG. 2. Reflected-light optical microscope photographs showing the ore mineralogy. A. Typical textures of pyrrhotite (Po) coarse-granular pentlandite $(\mathrm{Pn})$, chalcopyrite (Ccp), and chromite (Chr). Note the maucherite grain (Mch) included between chromite crystals. B. Granular chalcopyrite within pyrrhotite and idiomorphic to subidiomorphic chromites. C. Rounded grain of maucherite hosted by pyrrhotite. D.-E. Rounded to subrounded maucherites partial to totally including idiomorphic chromites. F. Maucherites with curved boundaries located in the interphase between pyrrhotite and chromite. G. Globular maucherites surrounded by thin rims of cobaltite-gersdorffite. H. Nickeline (Niq, with pink color) in the core of maucherite situated between chromite grains. Note small fingers of westerveldite (Ws) within the maucherite grain. 
TABLE 1. Electron Microprobe Analyses of Pyrrhotite, Pentlandite, Chalcopyrite, and Maucherite from Amasined Samples

\begin{tabular}{|c|c|c|c|c|c|c|c|c|c|c|c|c|c|c|}
\hline Mineral & & $\begin{array}{c}\mathrm{S} \\
(\text { wt } \%)\end{array}$ & $\begin{array}{c}\text { As } \\
(\text { wt } \%)\end{array}$ & $\begin{array}{c}\mathrm{Fe} \\
(\text { wt \%) }\end{array}$ & $\begin{array}{c}\text { Co } \\
\text { (wt \%) }\end{array}$ & $\begin{array}{c}\mathrm{Ni} \\
(\text { wt \%) }\end{array}$ & $\begin{array}{c}\mathrm{Cu} \\
(\text { wt \%) }\end{array}$ & Total & $\begin{array}{c}\text { S } \\
(\text { apfu) }\end{array}$ & $\begin{array}{c}\text { As } \\
(\mathrm{apfu})\end{array}$ & $\begin{array}{c}\mathrm{Fe} \\
(\mathrm{apfu})\end{array}$ & $\begin{array}{c}\text { Co } \\
(\mathrm{apfu})\end{array}$ & $\begin{array}{c}\mathrm{Ni} \\
(\mathrm{apfu})\end{array}$ & $\begin{array}{c}\mathrm{Cu} \\
(\mathrm{apfu})\end{array}$ \\
\hline \multirow{8}{*}{$\begin{array}{l}\text { Pyrrhotite } \\
(n=11) \\
\text { Pentlandite } \\
(n=8) \\
\text { Chalcopyrite } \\
(n=10) \\
\text { Maucherite } \\
(n=15)\end{array}$} & Avg & 38.42 & \multirow[t]{2}{*}{$<0.1$} & 60.88 & $<0.1$ & 0.12 & \multirow[t]{2}{*}{$<0.1$} & 99.86 & \multirow[t]{2}{*}{1.00} & & 0.91 & & \multicolumn{2}{|l|}{0.001} \\
\hline & S.D. & 0.46 & & 1.36 & & 0.05 & & 0.93 & & & 0.07 & & 0.001 & \\
\hline & Avg & 35.00 & \multirow{2}{*}{$<0.1$} & 27.62 & 1.22 & 35.32 & \multirow{2}{*}{$<0.1$} & 99.16 & 8.40 & & 3.81 & 0.16 & \multicolumn{2}{|l|}{4.63} \\
\hline & S.D. & 0.45 & & 1.23 & 0.20 & 0.46 & & 0.64 & 0.33 & & 0.22 & 0.02 & \multicolumn{2}{|l|}{0.55} \\
\hline & Avg & 35.43 & \multirow[t]{2}{*}{$<0.1$} & 30.39 & $<0.1$ & $<0.1$ & 32.79 & 99.00 & 2.04 & & 1.00 & & & 0.95 \\
\hline & S.D. & 0.21 & & 0.22 & & & 0.57 & 0.50 & 0.01 & & 0.01 & & & 0.01 \\
\hline & Avg & 0.24 & 45.05 & 0.27 & 0.47 & 52.65 & 0.16 & 99.05 & 0.09 & 7.51 & 0.06 & 0.10 & 11.20 & 0.005 \\
\hline & S.D. & 0.08 & 0.59 & 0.17 & 0.08 & 0.69 & 0.02 & 1.10 & 0.03 & 0.05 & 0.04 & 0.02 & 0.05 & 0.01 \\
\hline
\end{tabular}

Notes: Sample name = AM-2, Avg = average, S.D. = standard deviation, $n=$ number of grains analyzed, wt = weight, apfu = atoms per formula unit; recalculation was based on 17 apfu in pentlandite, 4 apfu in chalcopyrite, 19 apfu in maucherite, and $\mathrm{S}=1$ apfu in pyrrhotite

galena for $\mathrm{S}$, pure metals for $\mathrm{Ni}, \mathrm{Fe}, \mathrm{Co}$, and $\mathrm{Cu}$ and $\mathrm{GaAs}$ for As. The trace elements were determined using laser ablation inductively coupled plasma mass spectrometry (LA-ICP-MS) at LabMaTer, Université du Quebec à Chicoutimi (UQAC), Canada. Of the arsenides only maucherite could be analyzed because of the small grain size of nickeline and cobaltite. Because these minerals represent a minor proportion of the ore assemblage and are absent in most cases, neglecting these fine-grained phases does not materially affect the mass-balance calculation. Chromite was also analyzed, but it contained PGE values below the detection limit (Fig. 3A), so it does not have any effect on the estimation of partition coefficients. The UQAC laser ablation system consists of an Agilent 7700x mass spectrometer with an Excimer 193nm Resonetics Resolution M-50 laser ablation probe. Samples, reference materials, and blanks were placed in the sample chamber together
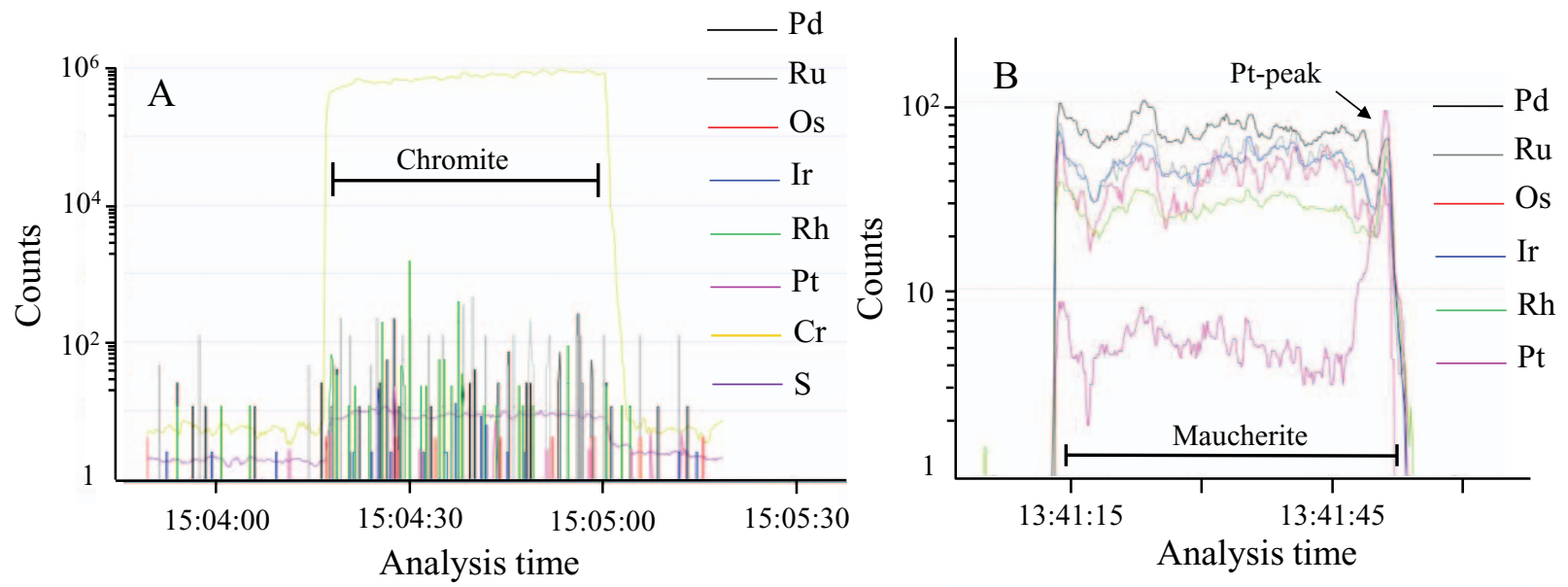

Analysis time

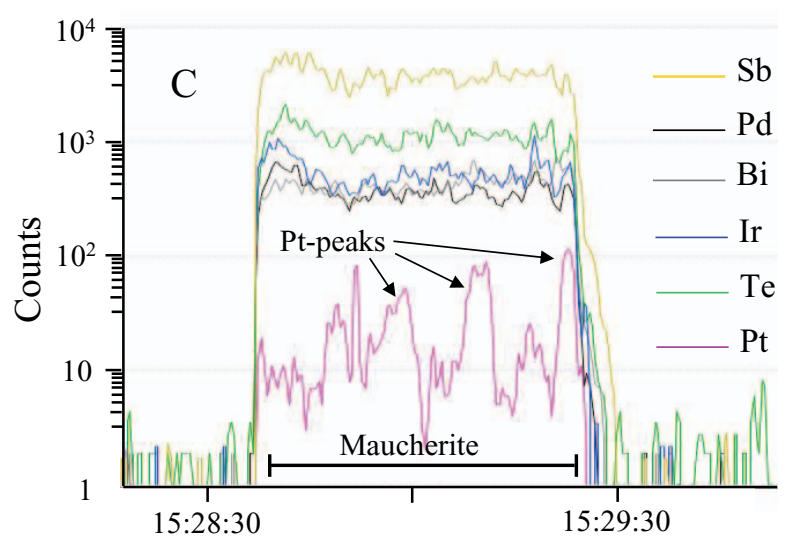

Analysis time

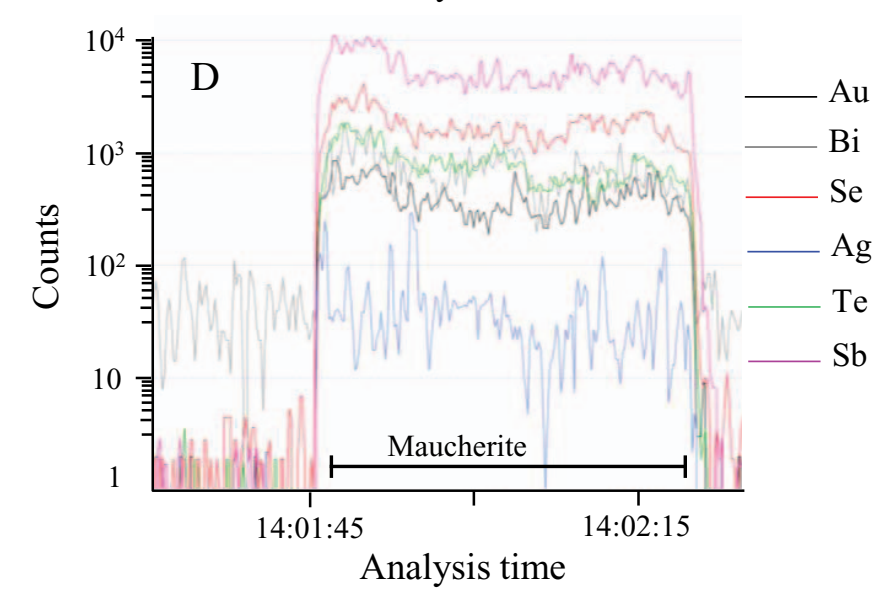

FIG. 3. Spectra of element abundances in chromite (A) and maucherite (B-D) obtained by LA-ICP-MS. Note that the abundances in chromite are similar to background and the signal for Pt in maucherite is much more irregular than for the rest of PGE whose laser ablation signal is quite flat and stable. 
and the reference materials were run at the beginning and end of each run. Line scans across the arsenide globules and sulfide grains were carried out using a beam of $55 \mu \mathrm{m}$, a laser frequency of $15 \mathrm{~Hz}$, a power of $0.5 \mathrm{~mJ} / \mathrm{cm}^{3}$, and a speed of lateral laser displacement of $5 \mu \mathrm{m} / \mathrm{s}$. The following isotopes were analyzed: ${ }^{29} \mathrm{Si},{ }^{33} \mathrm{~S},{ }^{34} \mathrm{~S},{ }^{53} \mathrm{Cr},{ }^{57} \mathrm{Fe},{ }^{59} \mathrm{Co},{ }^{60} \mathrm{Ni},{ }^{61} \mathrm{Ni},{ }^{63} \mathrm{Cu}$, ${ }^{65} \mathrm{Cu},{ }^{66} \mathrm{Zn},{ }^{68} \mathrm{Zn},{ }^{75} \mathrm{As},{ }^{82} \mathrm{Se},{ }^{101} \mathrm{Ru},{ }^{103} \mathrm{Rh},{ }^{105} \mathrm{Pd},{ }^{107} \mathrm{Ag},{ }^{108} \mathrm{Pd}$, ${ }^{111} \mathrm{Cd},{ }^{121} \mathrm{Sb},{ }^{125} \mathrm{Te},{ }^{187} \mathrm{Re},{ }^{189} \mathrm{Os},{ }^{193} \mathrm{Ir},{ }^{195} \mathrm{Pt},{ }^{197} \mathrm{Au},{ }^{208} \mathrm{~Pb}$, and ${ }^{209} \mathrm{Bi}$. Data reduction was carried out using Iolite software (Paton et al., 2011). Internal standardization for sulfides was based on ${ }^{57} \mathrm{Fe}$ by using the mean iron concentrations for each sulfide determined by the electron microprobe (Table 1). To calibrate for PGE and $\mathrm{Au}$, we used the certified reference material Laflamme po-727, which is a synthetic FeS doped with 40 ppm of each PGE and Au (Table A1) provided by the Memorial University of Newfoundland. For the rest of elements, we used the certified reference material MASS-1 (originally named PS-1), a $\mathrm{ZnCuFeS}$ pressed powder pellet provide by the U.S. Geological Survey and doped with 50 to $70 \mathrm{ppm} \mathrm{Ag}, \mathrm{As}, \mathrm{Bi}, \mathrm{Sb}, \mathrm{Se}$, and Te (Table A1). Two in-house reference materials, JB-MSS5 and UQAC-MSS-1, were used to monitor the accuracy of the calibration. JB-MSS5 is a synthetic FeS with 1 wt \% Ni, 20 to 65 ppm PGE, Au, Re, As, $\mathrm{Ag}, \mathrm{Bi}, \mathrm{Sb}, \mathrm{Se}$, and Te (Table Al) provided by J. Brenan of the University of Toronto. UQAC-MSS1 consists of a synthetic $\mathrm{NiFeS}_{2}$ provided by A. Peregoedova, doped with $\sim 2 \mathrm{ppm}$ PGE, Au, and Re (Table A1). This analytical protocol could not be used for maucherite because $\mathrm{Ni}$ is the only element available to use as an internal standard and both po-727 and MASS-1 contain very little Ni. Therefore we used JB-MSS5 to calibrate with ${ }^{61} \mathrm{Ni}$ as an internal standard, using a mean $\mathrm{Ni}$ value of 52.65 wt \% for the maucherite (Table 1). UQACMSS-1 was used as a monitor (Table A1). ${ }^{101} \mathrm{Ru}$ was corrected for ${ }^{61} \mathrm{Ni}$ interference by using UQAC-MSS1 and this correction is equivalent to $\sim 0.7 \mathrm{ppm}$ in pentlandite, $\sim 1.1 \mathrm{ppm}$ in maucherite, and less than detection level in pyrrhotite and chalcopyrite. ${ }^{103} \mathrm{Rh}$ and ${ }^{105} \mathrm{Pd}$ were corrected for ${ }^{63} \mathrm{Cu}^{40} \mathrm{Ar}$ and ${ }^{65} \mathrm{Cu}^{40} \mathrm{Ar}$, respectively, by running a $(\mathrm{CuFe}) \mathrm{S}_{2}$ blank at the beginning and end of each session. The $\mathrm{Cu}$ corrections on $\mathrm{Rh}$ and $\mathrm{Pd}$ in all the phases except chalcopyrite are less than detection levels. However, in chalcopyrite the corrections are too large to allow either ${ }^{103} \mathrm{Rh}$ or ${ }^{105} \mathrm{Pd}$ to be reported. Therefore, ${ }^{108} \mathrm{Pd}$ was used for chalcopyrite after correction for ${ }^{68} \mathrm{Zn}^{40} \mathrm{Ar}$ and ${ }^{108} \mathrm{Cd}$ interference, using ${ }^{111} \mathrm{Cd}$, and ${ }^{103} \mathrm{Rh}$ was not reported. When laser spectra revealed the presence of Ptbearing microinclusions within maucherite, we excluded these Pt peaks in the data reduction when inferring the concentration of Pt in solid solution in maucherite. Detection limits for laser analyses were calculated using background counts for the gas blank and each sulfide and arsenide analyses. Tables with the individual analyses for maucherite and sulfides are provided as supplementary electronic material (Tables A2, A3) and a summary with the concentrations are listed in Table 2.

\section{Trace Element Contents in Maucherite and Sulfide Minerals}

\section{Maucherite}

Maucherite contains significant amounts of all PGE (Tables 2, A2), with total PGE contents ranging between 77 and 195

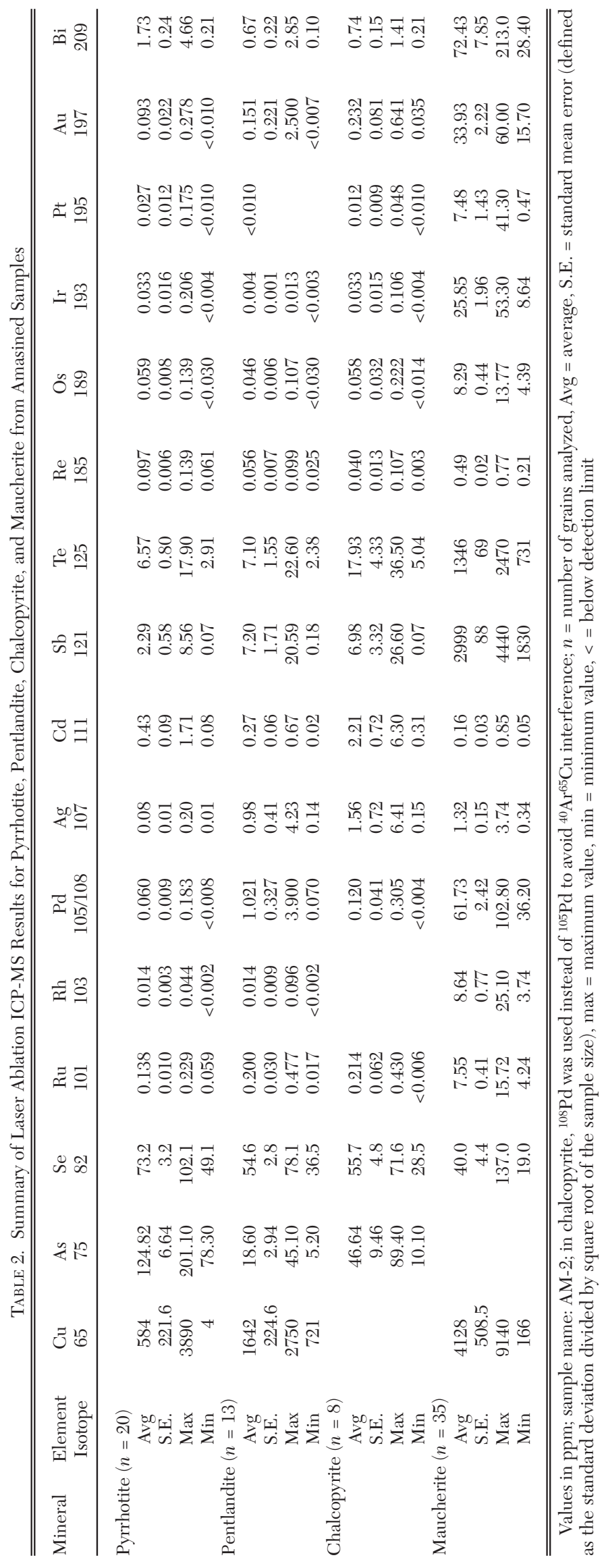


ppm. The average whole-rock content-normalized pattern of maucherite is quite flat, with PGE amounts around 100 times the whole-rock values (Fig. 4). Palladium is the most abundant PGE, with contents ranging from 36 to $103 \mathrm{ppm}(61.7 \pm$ $2.4 \mathrm{ppm}$; average and standard error). These Pd concentrations are in agreement with those obtained by Gervilla et al. (2004) using micro-PIXE (18-64 ppm) and electron probe microanalyses (21-82 ppm). Osmium, $\mathrm{Ru}$, and Rh show quite similar, homogeneous contents: from 4.4 to 13.8 ppm Os (8.3 $\pm 0.4 \mathrm{ppm})$, from 4.2 to $15.7 \mathrm{ppm} \mathrm{Ru}(7.5 \pm 0.4 \mathrm{ppm})$, and from 3.7 to $25.1 \mathrm{ppm} \mathrm{Rh}(8.6 \pm 0.8 \mathrm{ppm})$. Iridium contents are higher, between 8.6 and $53.3 \mathrm{ppm}(25.8 \pm 2.0 \mathrm{ppm})$. The ICP-MS signal for all these elements is quite flat and constant (Fig. 3B), suggesting that they are in solid solution within maucherite and not as platinum group minerals. In contrast, the ICP-MS signal for Pt is much more erratic and irregular, and usually shows narrow and well-defined peaks that do not correlate with any other element (Fig. 3B-C). This irregular pattern suggests that $\mathrm{Pt}$ does not only occur in solid solution within maucherite but is also present as submicroscopic inclusions, probably sperrylite, $\mathrm{PtAs}_{2}$, or native Pt. The Pt contents present in solid solution are variable, between 0.5 and $41.3 \mathrm{ppm}(7.5 \pm 1.4 \mathrm{ppm})$. If the Pt peaks are included in the data reduction, Pt reaches values as high as 308 and 173 ppm. The other analyzed elements occur in variable proportions. Rhenium commonly ranges between 0.21 and $0.77 \mathrm{ppm}$ $(0.49 \pm 0.02 \mathrm{ppm})$. The ICP-MS signals for Te, Bi, Se, and Sb are quite stable (Fig. 3C-D). Tellurium and Bi range from 731 to $2,470 \mathrm{ppm}$ Te and from 28 to $213 \mathrm{ppm} \mathrm{Bi}$, but commonly below 1,500 and 100 ppm, respectively. Selenium commonly ranges from 19 to $87 \mathrm{ppm}$ and Sb contents are the highest of the semimetals (1,830-4,440 ppm). Finally, Au and Ag concentrations range between 16 and $60 \mathrm{ppm} \mathrm{Au}(33.9 \pm 2.2$ ppm) and between 0.34 and $3.74 \mathrm{ppm} \mathrm{Ag}(1.3 \pm 0.2 \mathrm{ppm})$. The ICP-MS signal for $\mathrm{Au}$ is quite constant indicating that it is in solid solution but Ag shows a somewhat erratic signal (Fig. 3D), possibly due to Ag inclusions.

\section{Pyrrhotite, pentlandite, and chalcopyrite}

Pyrrhotite, pentlandite, and chalcopyrite are much less enriched in all PGE compared to maucherite (Fig. 4, Tables 2, A3). With the exception of some pentlandite grains which contain up to $3.9 \mathrm{ppm} \mathrm{Pd}$, all PGE occurs in amounts lower than $1 \mathrm{ppm}$. Pyrrhotite hosts some $\mathrm{Ru}(0.14 \pm 0.01 \mathrm{ppm}), \mathrm{Rh}$ $(0.014 \pm 0.003 \mathrm{ppm}), \mathrm{Pd}(0.06 \pm 0.01 \mathrm{ppm}), \mathrm{Os}(0.06 \pm 0.01$ ppm), and $\operatorname{Ir}(0.03 \pm 0.02 \mathrm{ppm})$, whereas Pt is usually below or close to the detection limit $(\sim 0.010 \mathrm{ppm})$. Pentlandite contains appreciable amounts of Pd (commonly from 0.2-0.9 ppm) and $\mathrm{Ru}(0.2 \pm 0.03 \mathrm{ppm})$, whereas chalcopyrite hosts some $\mathrm{Ru}(0.21 \pm 0.06 \mathrm{ppm})$ and $\mathrm{Pd}(0.12 \pm 0.04 \mathrm{ppm})$. As for pyrrhotite, Ir and Pt are typically below or close to the detection limit in pentlandite and chalcopyrite $(\sim 0.004$ and 0.010 ppm for Ir and Pt, respectively).

Bismuth, Te, and $\mathrm{Sb}$ contents are much lower in sulfides than in maucherite; $\mathrm{Bi}$ and $\mathrm{Sb}$ are typically below 1 and 9 ppm, respectively, whereas Te ranges from 2.9 to $17.9 \mathrm{ppm}$ in pyrrhotite $(6.6 \pm 0.8 \mathrm{ppm})$ and from 2.4 to $22.6 \mathrm{ppm}$ in pentlandite $(7.1 \pm 1.6 \mathrm{ppm})$, being slightly higher in chalcopyrite (from 5-36.5 ppm, $17.9 \pm 4.3 \mathrm{ppm}$ ). In contrast, Se and $\mathrm{Ag}$ contents are quite similar to those of maucherite, even slightly higher in the pyrrhotite for Se. Selenium ranges from 49 to $102 \mathrm{ppm}$ in pyrrhotite $(73.2 \pm 3.2 \mathrm{ppm})$, from 36 to 78 ppm in pentlandite $(54.6 \pm 2.8 \mathrm{ppm})$, and from 28 to $72 \mathrm{ppm}$ in chalcopyrite $(55.7 \pm 4.8 \mathrm{ppm})$, whereas $\mathrm{Ag}$ is typically below $0.2 \mathrm{ppm}$ in pyrrhotite, and $1 \mathrm{ppm}$ in pentlandite and chalcopyrite (some grains of pentlandite and chalcopyrite have up to 4.2 and $6.4 \mathrm{ppm} \mathrm{Ag}$, respectively). Rhenium is only slightly lower in sulfides than in maucherite, varying from 0.06 to $0.14 \mathrm{ppm}$ in pyrrhotite, from 0.025 to $0.1 \mathrm{ppm}$ in pentlandite, and up to $0.1 \mathrm{ppm}$ in chalcopyrite. Finally, $\mathrm{Au}$ is

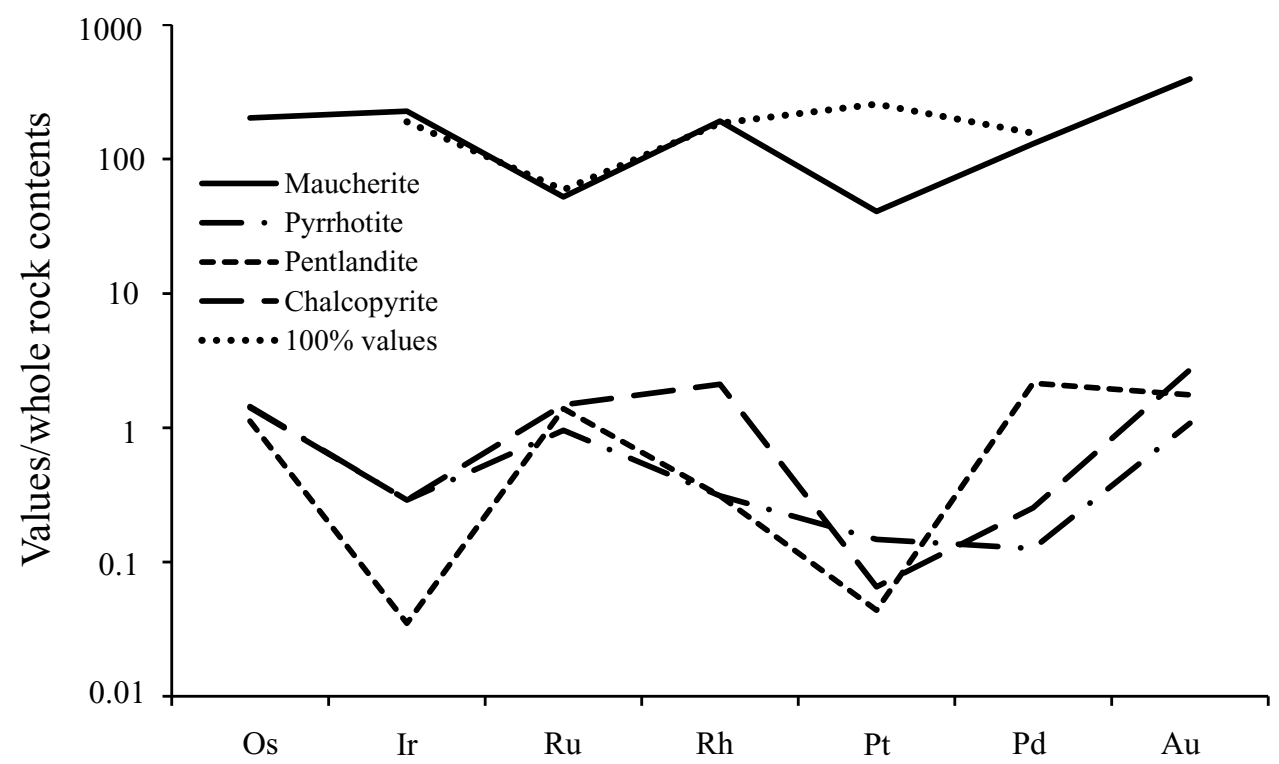

FIG. 4. Patterns with the average PGE and Au contents for maucherite, pyrrhotite, pentlandite, and chalcopyrite normalized to the whole-rock concentrations. Whole-rock values, listed in Table 3, are from Gervilla et al. (1996). The wholerock values recalculated to $100 \%$ sulfide/arsenide (100\% values) are also shown for comparison. 
strongly depleted in sulfides; it is usually below $0.3 \mathrm{ppm}$ in pyrrhotite, up to $2.5 \mathrm{ppm}$ in pentlandite, and below $0.64 \mathrm{ppm}$ in chalcopyrite.

\section{Partition Coefficients Between Arsenide and Sulfide Minerals}

\section{Mass-balance calculation}

Before calculating the partition coefficients of PGE between arsenide and sulfide phases using the concentrations obtained by LA-ICP-MS, it is important to know whether arsenide and sulfide minerals contain the bulk of PGE of the samples. In other words, it is critical to determine whether arsenide and sulfide minerals have partial or totally lost PGE (e.g., in form of exsolutions of PGM), what would imply that their PGE contents would be lower than those original, giving rise to unrealistic partition coefficients. To test this, we have carried out a mass-balance calculation in order to determine the percentage of each PGE present in maucherite, pyrrhotite, pentlandite, and chalcopyrite. For this calculation, we have used the average content in PGE and weight fraction of each mineral, and the whole-rock PGE concentration previously published by Gervilla et al. (1996) and summarized in Table 3. The weight fraction was calculated assuming that all sulfide minerals presents in the samples are pyrrhotite, pentlandite, and chalcopyrite, and all arsenide minerals are maucherite. This assumption is considered to be a valid approximation because the other arsenide minerals, nickeline and cobaltite-gersdorffite, are very minor, being even absence in most polished blocks. Thus, all As in whole rock is assigned to be in maucherite. The weight fraction of maucherite $\left(\mathrm{F}_{\mathrm{Mch}}\right)$ is then given by $\mathrm{As}_{\mathrm{WR}} / \mathrm{As} s_{\mathrm{Mch}}$, where $\mathrm{As} \mathrm{s}_{\mathrm{WR}}$ is the As whole-rock content and $\mathrm{As}_{\mathrm{Mch}}$ is the average of As in maucherite (45.05 wt $\%$, Table 1$)$. The weight fraction of pentlandite $\left(\mathrm{F}_{\mathrm{Pn}}\right)$ is given by $\mathrm{Ni}_{W R} / \mathrm{Ni}_{\mathrm{Pn}}$, where $\mathrm{Ni}_{\mathrm{WR}}$ is the $\mathrm{Ni}$ concentration in the whole rock after extracting the $\mathrm{Ni}$ content consumed by maucherite, and $\mathrm{Ni}_{\mathrm{Pn}}$ is the average $\mathrm{Ni}$ content of pentlandite. The Ni content of pyrrhotite $(0.12$ wt $\%$, Table 1$)$ only decreases the $\mathrm{F}_{\mathrm{Pn}}$ from 0.138 to 0.136 , thus this correction does not have any significant effect on the mass-balance and partition coefficient calculations. Likewise, if the As content in sulfide minerals is considered (Table 2), the $\mathrm{F}_{\text {Mch }}$ decreases slightly from 0.0042 to 0.0039 , but this decrease only generates a minor variation in the percentage of $\mathrm{Ni}$ consumed by maucherite (from $0.220-0.205$ wt \%) so it does not modify $\mathrm{F}_{\mathrm{Pn}}$ or the weight fraction of pyrrhotite. All $\mathrm{Cu}$ is considered to be in chalcopyrite, so the weight fraction of chalcopyrite $\left(\mathrm{F}_{\mathrm{Cpp}}\right)$ is given by $\mathrm{Cu}_{\mathrm{WR}} / \mathrm{Cu}_{\mathrm{Ccp}}$, where $\mathrm{Cu}_{\mathrm{WR}}$ is the $\mathrm{Cu}$ wholerock content, and $\mathrm{Cu}_{\mathrm{Cpp}}$ is the average $\mathrm{Cu}$ content in chalcopyrite. Finally, the weight fraction of pyrrhotite $\left(\mathrm{F}_{\mathrm{Po}}\right)$ was calculated assuming that the remaining $\mathrm{S}$, after subtracting the $\mathrm{S}$ consumed by pentlandite and chalcopyrite, corresponds to pyrrhotite. Then, the $\mathrm{F}_{\mathrm{Po}_{\mathrm{o}}}$ is $\left[\mathrm{S}_{\mathrm{WR}}-\left(\mathrm{F}_{\mathrm{Pn}} \mathrm{X} \mathrm{S}_{\mathrm{Pn}}+\mathrm{F}_{\mathrm{Cpp}} \mathrm{X} \mathrm{S}_{\mathrm{Cp}}\right)\right] / \mathrm{S}_{\mathrm{Po}}$, where $S_{\mathrm{WR}}, S_{\mathrm{P}_{n}}, S_{\mathrm{Ccp}}$, and $S_{\mathrm{Po}_{0}}$ are the whole-rock $\mathrm{S}$ content, and the average $\mathrm{S}$ contents of pentlandite, chalcopyrite, and pyrrhotite, respectively. The low S content of maucherite ( 0.26 wt \%, Table A2) along with its low weight fraction $(0.0042)$ produces a negligible effect on the weight fraction of sulfide phases. For the purposes of the mass-balance calculation, where the values obtained by LA-ICP-MS were below the detection limit, we assumed a value of half of the detection limit for that element.

Results of the mass-balance calculation are listed in Table 3 and a histogram with the percentages of each element hosted by each mineral is shown in Figure 5. We assume the error involving the sample mass analyzed for whole rock does not represent exactly the same sample mass studied by LA-ICPMS. Maucherite and sulfides host the totality of whole-rock $\mathrm{Os}, \mathrm{Ir}, \mathrm{Ru}, \mathrm{Rh}$, and Pd content. In detail, maucherite accounts for most $\operatorname{Ir}(95.7 \%)$, Os (84.9\%), Rh (81.5\%), and Pd (54.6\%), whereas pyrrhotite accounts for most $\mathrm{Ru}(54.8 \%$, with only $22.1 \%$ coming from maucherite) and some $\mathrm{Rh}(17.9 \%)$ and Ir (16.6\%). Pentlandite accounts for $29.7 \% \mathrm{Pd}$ and $19.2 \% \mathrm{Ru}$, contributing very little to the $\mathrm{Rh}(4.3 \%)$ and $\operatorname{Ir}(0.5 \%)$ balance. The calculated proportion of Os and Au held in maucherite and sulfide minerals is well in excess of $100 \%$

TABle 3. Bulk PGE, S, Ni, Cu, As and Au Concentration of the Analyzed Amasined Samples, Mass-Balance Calculation, and Calculated Composition of the Original As-Rich Sulfide Melt

\begin{tabular}{|c|c|c|c|c|c|c|c|c|c|c|c|}
\hline & $\begin{array}{c}\mathrm{S} \\
(\%)\end{array}$ & $\begin{array}{c}\text { As } \\
(\mathrm{ppm})\end{array}$ & $\begin{array}{c}\mathrm{Ni} \\
(\%)\end{array}$ & $\begin{array}{l}\mathrm{Cu} \\
(\%)\end{array}$ & $\begin{array}{c}\text { Os } \\
(\mathrm{ppb})\end{array}$ & $\begin{array}{c}\mathrm{Ir} \\
(\mathrm{ppb})\end{array}$ & $\begin{array}{c}\mathrm{Ru} \\
(\mathrm{ppb})\end{array}$ & $\begin{array}{c}\mathrm{Rh} \\
(\mathrm{ppb})\end{array}$ & $\begin{array}{c}\mathrm{Pt} \\
(\mathrm{ppb})\end{array}$ & $\begin{array}{c}\mathrm{Pd} \\
(\mathrm{ppb})\end{array}$ & $\begin{array}{c}\mathrm{Au} \\
(\mathrm{ppb})\end{array}$ \\
\hline \multicolumn{12}{|c|}{$\underline{\text { Whole-rock content of the studied samples }}^{1}$} \\
\hline & 27.5 & 1880 & 5.09 & 0.713 & 41 & 114 & 144 & 45 & 183 & 475 & 86 \\
\hline \multicolumn{12}{|c|}{$\underline{\text { Mass-balance calculation (\% of each element present in each mineral) }}$} \\
\hline Maucherite & & & & & 84.9 & 95.7 & 22.1 & 81.5 & 17.2 & 54.6 & 165.7 \\
\hline Pyrrhotite & & & & & 82.0 & 16.6 & 54.8 & 17.9 & 8.4 & 7.2 & 61.6 \\
\hline Pentlandite & & & & & 15.4 & 0.5 & 19.2 & 4.3 & 0.6 & 29.7 & 24.2 \\
\hline Chalcopyrite & & & & & 3.1 & 0.6 & 3.3 & & 0.1 & 0.6 & 5.9 \\
\hline Total & & & & & 185.4 & 113.4 & 99.4 & 103.7 & 26.3 & 92.1 & 257.4 \\
\hline
\end{tabular}

Composition of the original, As-rich sulfide melt (calculated from in situ concentrations and weight fraction of pyrrhotite, pentlandite, chalcopyrite, and maucherite; values in $\mathrm{ppb}$ )

${ }^{1}$ Data from Gervilla et al. (1996): bulk compositions were analyzed by X-Ray Assay Laboratories Ltd., Don Mills, Ontario, by fire-assay preconcentration followed by neutron activation; the detection limits were 1 ppb for $\mathrm{Au}, \mathrm{Pd}, \mathrm{Pt}, \mathrm{Ru}, \mathrm{Rh}$, and Ir, and 3 ppb for Os 


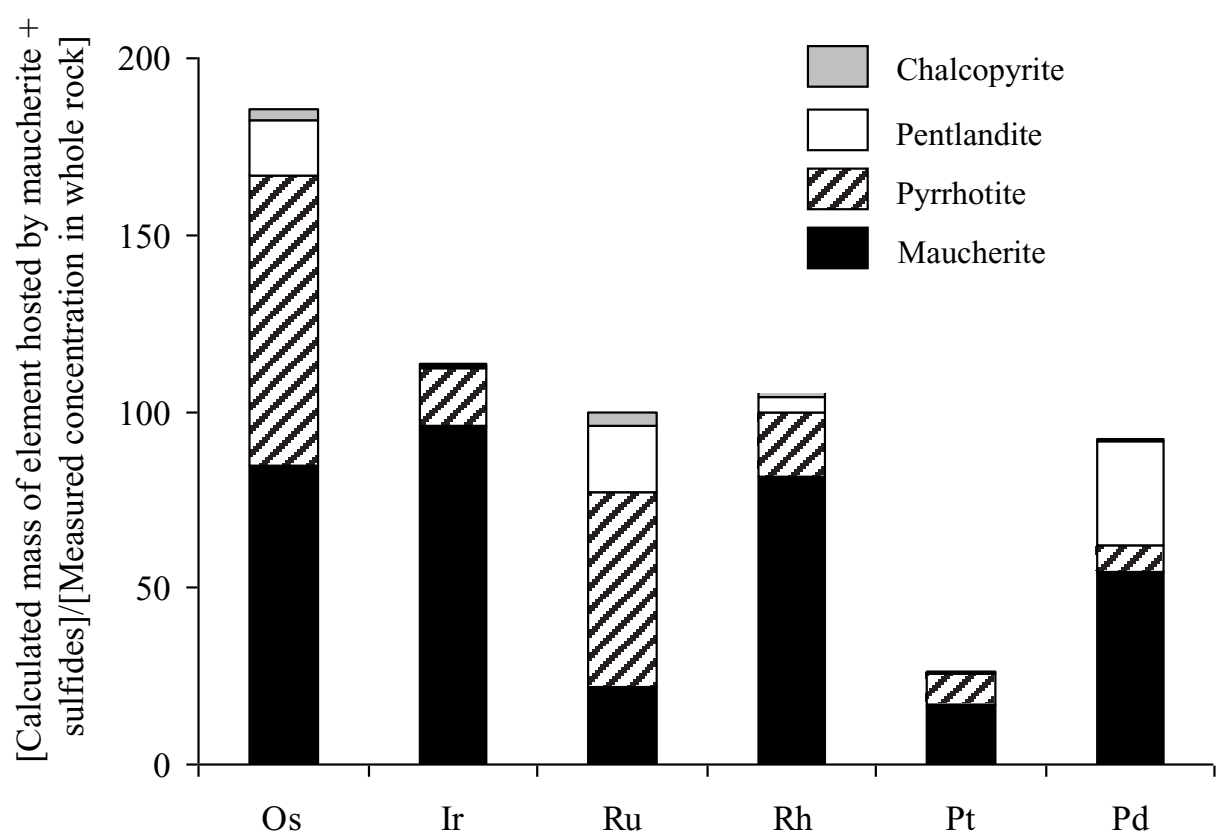

FIG. 5. Mass balance of PGE represented as the calculated mass of each element hosted by maucherite, pyrrhotite, pentlandite, and chalcopyrite divided by the measured concentration in whole rock.

( $185.4 \%$ and $257.4 \%$, respectively), suggesting either the in situ contents of these elements in these minerals are an overestimate or the whole-rock contents of Os and Au are too low due to analytical losses. Another, more likely, explanation is sampling uncertainty: the sample surface analyzed in the polished sections and the rock volume represented in the wholerock analyses are not representative of the same rock mass for these elements. This is an implicit problem in all metal massbalance calculations and is especially prevalent in low-level trace elements with heterogeneous grain-scale distributions. The percentages close to $100 \%$ for Ir, $\mathrm{Ru}, \mathrm{Rh}$, and Pd (Table 3) are consistent with the absence of PGM carrying these elements and indicate that these elements are entirely hosted within maucherite and sulfide minerals. In the absence of PGM, the PGE content of the original As-rich sulfide melt ( $\mathrm{C}_{i}^{\text {liq }}$, before the crystallization of maucherite) can be estimated using the following expression:

$$
\begin{aligned}
\mathrm{C}_{i}^{\text {liq }}=\mathrm{F}_{\mathrm{Mch}} & \times \mathrm{C}_{i}^{\mathrm{Mch}}+ \\
& \mathrm{F}_{\mathrm{Po}} \times \mathrm{C}_{i}^{P_{0}}+\mathrm{F}_{\mathrm{Pn}} \times \mathrm{C}_{i}^{P_{n}}+\mathrm{F}_{\mathrm{Ccp}} \times \mathrm{C}_{i}^{C c p},
\end{aligned}
$$

where $\mathrm{C}_{i}^{M c h}, \mathrm{C}_{i}^{P o}, \mathrm{C}_{i}^{P n}$, and $\mathrm{C}_{i}^{C c p}$ are the average content of the element $i$ in maucherite, pyrrhotite, pentlandite, and chalcopyrite, respectively. There is an excellent positive correlation between the calculated composition for each PGE using equation (1; Table 3$)$ and its measured whole-rock content $(\rho$ $=0.86$, Fig. 6), which is even almost perfect $(\rho=0.99)$ if $\mathrm{Pt}$, which deviates away the main trend, is not considered. Furthermore, if the correlation line is projected to the value of $\mathrm{x}$ $=0$ (i.e., no PGE in maucherite and sulfide minerals), the whole-rock value is also almost $0(\sim 0.02 \mathrm{ppm})$, supporting the conclusion that maucherite and sulfide minerals account for $\mathrm{Os}, \mathrm{Ir}, \mathrm{Ru}, \mathrm{Rh}$, and Pd of the rock. The situation is somewhat different for Pt. The percentage of whole-rock Pt content that is hosted in maucherite and sulfide minerals is unusually low in comparison with the other PGE, only $26.3 \%$. Maucherite is the main carrier of $\mathrm{Pt}$ but with much lower proportion, $17.2 \%$, than the other PGE. It is important to indicate that for this calculation we have used the $\mathrm{Pt}$ concentrations in maucherite without taking into account the Pt peaks interpreted as microinclusions. Thus, this low percentage confirms that a high proportion of Pt occurs as a different phase; probably submicroscopic Pt-bearing PGM, such as is indicated by the ICP-MS signal (Fig. 3B-C). Pyrrhotite only contributes with $8.4 \%$, whereas the Pt coming from pentlandite and chalcopyrite is negligible, $0.6 \%$ and $0.1 \%$, respectively.

Mass-balance calculation for $\mathrm{Re}, \mathrm{Te}, \mathrm{Bi}, \mathrm{Se}, \mathrm{Sb}$, and $\mathrm{Ag}$ was not possible due to the lack of whole-rock data for the samples. However, based on the stable ICP-MS signal for these elements (Fig. 3C-D), their high contents in maucherite and the lack of mineral inclusions containing these elements, we infer that their concentrations in the arsenide and sulfide minerals probably approximate to original value. The partition coefficients were calculated on this basis.

\section{Partition coefficient calculation}

The partition coefficient for a given element between arsenide and sulfides $\left(\mathrm{D}_{i}^{A s s u l f}\right)$ is given by the following equation:

$$
\mathrm{D}_{i}^{\text {Assulf }}=\mathrm{C}_{i}^{\text {As }} / \mathrm{C}_{i}^{\text {Sulf }},
$$

where $\mathrm{C}_{i}^{A s}$ and $\mathrm{C}_{i}^{\text {Sulf }}$ represent the concentrations of the element $i$ in the arsenide and sulfide phases, respectively. In our case, the $\mathrm{C}_{i}^{A s}$ corresponds to the content in maucherite, whereas $\mathrm{C}_{i}^{\mathrm{Sulf}}$ represents the content of the element in the sulfide melt after maucherite crystallization from where pyrrhotite, pentlandite, and chalcopyrite form. Hence, $\mathrm{C}_{i}^{\text {Sulf }}$ is given by $\left(\mathrm{F}_{\mathrm{Po}} \mathrm{C}_{i}^{P o}\right) / \mathrm{F}_{\text {sulf }}+\left(\mathrm{F}_{\mathrm{Pn}} \mathrm{C}_{i}^{P n}\right) / \mathrm{F}_{\text {sulf }}+\left(\mathrm{F}_{\mathrm{Ccp}} \mathrm{C}_{i}^{C c p}\right) / \mathrm{F}_{\text {sulf }}$, 


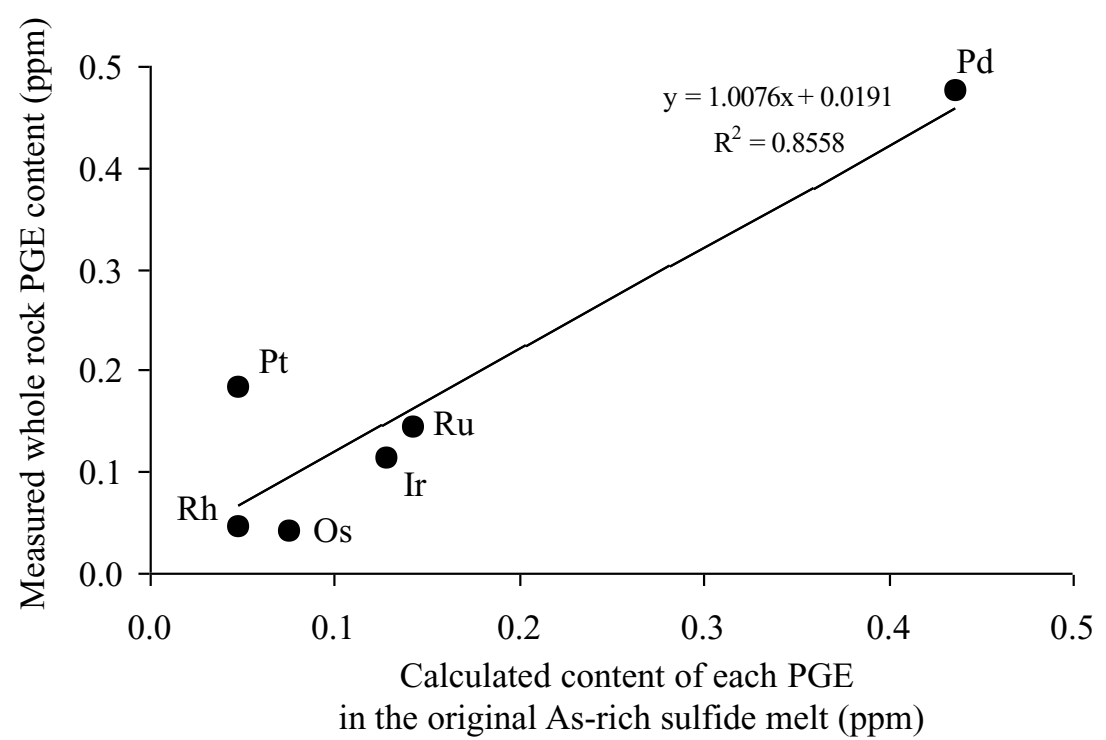

FIG. 6. Measured whole-rock content of each PGE vs. calculated compositions for each PGE in the original As-rich sulfide melt. See text for explanation.

being $\mathrm{C}_{i}^{P_{0}}, \mathrm{C}_{i}^{P_{n}}$, and $\mathrm{C}_{i}^{C c p}$ the average contents of the element $i$ in pyrrhotite, pentlandite, and chalcopyrite, respectively, and $\mathrm{F}_{\text {sulf }}$ the total weight fraction of sulfides defined as the sum of the weight fraction of pyrrhotite, pentlandite, and chalcopyrite. Table 4 lists the concentrations reported for PGE, Re, Au, Ag, Se, Te, Bi, and $\mathrm{Sb}_{\text {for }} \mathrm{C}_{i}^{A s}$ and $\mathrm{C}_{i}^{\text {sulf }}$, and the partition coefficients obtained using equation (2). The partition coefficients are calculated using a combination of mineral analyses, modal proportion estimations, and whole-rock data, all introducing errors into the calculation. With the aim of estimating the uncertainty into the partition coefficients, Table 4 also includes the standard mean error in the estimations of $\mathrm{C}_{i}^{A s}$ and $\mathrm{C}_{i}^{\text {Sulf }}$ and the resultant propagating error into the partition coefficients.

All PGE are highly compatible with the arsenide phase: $\mathrm{D}_{I r}^{\text {Assulf }}=920, \mathrm{D}_{R h}^{\text {Ass sulf }}=620, \mathrm{D}_{P t}^{\text {Ass sulf }}=330, \mathrm{D}_{P d}^{\text {Assulf }}=250$, $\mathrm{D}_{O s}^{A s s s u f f}=140$, and $\mathrm{D}_{R u}^{A s s s u l f}=50$. The Pt value is a minimum estimation because we excluded in this calculation the Pt present as microinclusions. In this way, if the Pt peaks are taking into account, some maucherite grains reach values as high as 308 and $173 \mathrm{ppm}$, and the average $\mathrm{C}_{P t}^{A s}$ and $\mathrm{D}_{P t}^{A s / s u l f}$ increase up to $20.08 \mathrm{ppm}$ and 870 , respectively. The whole-rock PGE concentrations were recalculated to $100 \%$ sulfide/arsenide and plotted in Figure 4 after normalization to the whole-rock contents. This recalculation was carried out bearing in mind that PGE are not only concentrated in arsenides but also in sulfides, thus the weight fractions and PGE concentrations in each sulfide phase were taking into account. The recalculated values are very closely to those of maucherite, suggesting that this phase controls the bulk PGE abundance. The 100\% recalculated value of $\mathrm{Pt}$ is higher than that of maucherite, meaning that $\mathrm{Pt}$ is also present as PGM. The $100 \%$ recalculation for Os and $\mathrm{Au}$ was not efficient due to the anomaly low whole-rock concentrations. The partition coefficient of $\mathrm{Au}$ is similar to that of the PGE, $\mathrm{D}_{A u}^{\text {Ass sulf }}=310$. Among the semimetals, $\mathrm{Sb}$ is the element with the highest partition coefficient, $\mathrm{D}_{S b}^{A_{S} / s u l f}=890$, followed by Te, $\mathrm{D}_{T e}^{\text {Ass sulf }}=190$, and $\mathrm{Bi}, \mathrm{D}_{B i}^{\text {Ass sulf }}=50$. In contrast, Se is slightly incompatible in the arsenides, $\mathrm{D}_{S e}^{\text {Asssulf }}=0.6$.

Table 4. Partition Coefficients for PGE, Au, Re, Ag, Se, Sb, Bi and Te Between Arsenide and Sulfide Phases Calculated from the Compositions Estimated for Each Phase

\begin{tabular}{|c|c|c|c|c|c|c|c|c|c|c|c|c|c|}
\hline & Os & $\mathrm{Ir}$ & $\mathrm{Ru}$ & $\mathrm{Rh}$ & $\mathrm{Pt}$ & $\mathrm{Pd}$ & $\mathrm{Au}$ & Re & $\mathrm{Ag}$ & $\mathrm{Se}$ & $\mathrm{Sb}$ & $\mathrm{Bi}$ & $\mathrm{Te}$ \\
\hline S.E. & 0.44 & 1.96 & 0.41 & 0.77 & 1.43 & 2.42 & 2.22 & 0.02 & 0.15 & 4.35 & 88.1 & 7.85 & 69.06 \\
\hline S.E. & 0.008 & 0.013 & 0.015 & 0.004 & 0.010 & 0.070 & 0.061 & 0.006 & 0.107 & 3.17 & 0.88 & 0.23 & 1.05 \\
\hline$D_{1}^{A s} /$ sulf & 140 & 920 & 50 & 620 & 330 & 250 & 310 & 6 & 4 & 0.60 & 890 & 50 & 190 \\
\hline S.E. & 30 & 500 & 10 & 230 & 200 & 80 & 200 & 0.6 & 2.1 & 0.10 & 260 & 10 & 40 \\
\hline
\end{tabular}

Contents in ppm. S.E. standard mean error. The concentration of the arsenide phase correspond to the average of the values in maucherite. Sulfide melt concentrations were estimated using the equation $\left(\mathrm{F}_{\mathrm{P}_{0}} \mathrm{C}_{\mathrm{i}}^{\mathrm{Po}}\right) / \mathrm{F}_{\text {sulf }}+\left(\mathrm{F}_{\mathrm{Pn}} \mathrm{C}_{\mathrm{i}} \mathrm{Pn}^{2}\right) / \mathrm{F}_{\text {sulf }}+\left(\mathrm{F}_{\mathrm{Ccp}} \mathrm{C}_{\mathrm{i}}^{\mathrm{Ccp}}\right) / \mathrm{F}_{\text {sulf, }}$, being $\mathrm{C}_{\mathrm{i}} \mathrm{P}^{\mathrm{Po}}, \mathrm{C}_{\mathrm{i}}^{\mathrm{Pn}}$ and $\mathrm{C}_{\mathrm{i}} \mathrm{Cpp}$ the average content of the element $i$ in pyrrhotite, pentlandite and chalcopyrite, respectively, $F_{P_{0}}, F_{P_{n}}$ and $F_{C c p}$ the weight fraction of each sulfide mineral, and $F_{\text {sulf }}$ the weight fraction of sulfides defined as $\mathrm{F}_{\mathrm{P}_{0}}+\mathrm{F}_{\mathrm{Pn}_{n}}+\mathrm{F}_{\mathrm{Ccp}}\left({ }^{*} \mathrm{Rh}\right.$ in chalcopyrite was not considered). $\mathrm{D}_{\mathrm{i}}{ }^{\mathrm{As} / \text { sulf: }}$ : partition coefficient between arsenide and sulfide phases for each element estimated as the concentration of the element in the arsenide phase divided by its concentration in the sulfide melt; standard error of $\mathrm{D}$ values were estimated as [(S.E. in arsenide phase/content in arsenide phase)+(S.E. in sulfide melt/content in sulfide melt)] "partition coefficient 
These results are in agreement with the strong correlation existent between $\mathrm{As}, \mathrm{Bi}$, Te, and $\mathrm{Sb}$ in magmatic sulfide natural systems where these elements are typically concentrated together in late-stage, semimetal-rich melts while Se contents only increase slightly (Zientek et al., 1994; Theriault and Barnes, 1998; Holwell and McDonald, 2010). Experimental work in sulfide systems (Helmy et al., 2007, 2010) also shows that $\mathrm{Sb}, \mathrm{Te}$, and $\mathrm{Bi}$ are highly incompatible into the crystallizing MSS (e.g., $\mathrm{D}_{S b}^{M S S / m e l t}=0.003$ ), concentrating in the fractionated liquid, while Se is only moderately incompatible $\left(\mathrm{D}_{S e}^{\text {MSS/melt }}\right.$ around 0.65$)$. Although these results might not be applicable to our case, they also indicate that Se is the element showing the strongest affinity for sulfide minerals among semimetals. In addition, the higher compatibility of $\mathrm{Sb}$ in maucherite in comparison with $\mathrm{Te}$ and $\mathrm{Bi}$ is in agreement with the distribution observed of these elements in the Dundonald Beach South deposit (Hanley, 2007). In this deposit, the Pd-Pt-rich, sulfarsenide-bearing mineralization is enriched in Sb by a factor of 85 relative to the PGE-poor, sulfide-rich mineralization, whereas $\mathrm{Te}$ and $\mathrm{Bi}$ are only enriched by a factor of 8 and 6 , respectively.

Finally, Re and Ag are only slightly compatible with the maucherite, $\mathrm{D}_{R e}^{A s s u l f}=6$ and $\mathrm{D}_{A g}^{A s / s u l f}=4$. This is in agreement with the empirical results for the Dundonald Beach South deposit, where the enrichment of Ag in the As-rich mineralization is very small in comparison with the other chalcophile elements (Hanley, 2007). Antimony, Bi, Te, Au, Pt, and Pd are enriched 10 to 100 times in the high-grade lens compared to typical low-grade sulfide mineralization, $\mathrm{Ag}$ is only slightly enriched 2 to 5 times.

\section{Geologic Implications}

The calculated partition coefficients clearly highlight the importance of arsenide phases as collectors of PGE and other chalcophile elements in magmatic sulfide systems. However, their geologic interpretation depends on the origin of the maucherite. The maucherite grains may represent either a mineral that crystallized at high temperature from the sulfide melt or the crystallization product of droplets of arsenide melt which segregated by immiscibility from sulfide melt due to As saturation as suggested by Gervilla et al. (1996). Maucherite grains are typically located within pyrrhotite (Fig. 2), which suggests that the arsenide phases formed before monosulfide solid solution (MSS). Furthermore, the maucherite is enriched in elements compatible with MSS, such as Re, Os, Ir, Ru, and Rh, which also indicates that it formed before MSS. The crystallization temperature of MSS of the composition observed here is $1,100^{\circ}$ to $1,050^{\circ} \mathrm{C}$. However, the upper thermal stability limit of maucherite is $830^{\circ} \mathrm{C}$ (Yund, 1961), which means that it cannot have crystallized from the sulfide melt before MSS. In contrast, if maucherite formed from an immiscible arsenide melt, such melt could have segregated before the crystallization of MSS. Thus, maucherite would form by a peritectic reaction of the earlyformed nickeline (which can start to crystallize at $962^{\circ} \mathrm{C}$ ) with small amounts of residual arsenide melt and vapor (Yund, 1961). Westerveldite likely formed from minor amounts of $\mathrm{Fe}$ present in the Ni-As melt. The globular texture of maucherite, analogous to sulfide globules found in basalts (e.g., Czamanske and Moore, 1977), as well as the presence of nickeline nuclei in some maucherite globules (Fig. 2H) support this interpretation.

Experimental studies have shown that As-rich melts can segregate by immiscibility from sulfide melts, scavenging the dissolved PGE (Makovicky et al., 1990, 1992; Fleet et al., 1993; Tomkins, 2010). Nevertheless, the formation of As-rich melts is an uncommon process that requires As saturation of the sulfide liquid, which typically contains As several orders of magnitude below those necessary for As saturation (Fleet et al., 1993, determined that sulfide melts require $~ 0.1 \mathrm{wt} \%$ As to reach As saturation). Hence, some As enrichment mechanism is required before segregation of an arsenide melt can take place. Arsenic concentrations in magmatic melts can significantly increase via assimilation of As-rich country rocks (e.g., As-rich shales) by the magmas (Gervilla et al., 1998; Hanley, 2007; Hutchinson and McDonald, 2008; Dare et al., 2010; Godel et al., 2012). The contaminated magmas could then reach sufficiently high As concentrations to segregate arsenide droplets by immiscibility. Alternatively, silicate melts deriving from the partial melting of metasomatized mantle sources could be enriched in As (Ishimaru and Arai, 2008) that would be introduced during metasomatism by fluids derived from subducting oceanic slab (Hattori et al., 2002). Several works have postulated a mantle origin for As in Beni Bousera (Lorand, 1987; Gervilla and Leblanc, 1990; Van der Wal and Bodinier, 1996; Crespo et al., 2006). According to this model, the S- and As-enriched melts correspond to highly fractionated small-volume melts originated during a major event of asthenospheric-derived melt percolation (Lenoir et al., 2001; Gervilla et al., 2002) onto an old metasomatized peridotite protolith. During this percolation event, the infiltrated melt reacted with the host rocks giving rise to small volume residual melts enriched in As, S, C, and metals. The anomalously high levels of As in some sample of nonpercolated garnet lherzolites (up to $4.8 \mathrm{ppm}$, Torres-Ruiz et al., 1991) and the presence of nickel arsenide in other samples of nonpercolated garnet pyroxenite (Lorand, 1987) point out the As-rich nature of the ultramafic protolith. Irrespective of the mechanism responsible for the As enrichment, the segregated arsenide droplets would sequester the PGE according to their partition coefficients with the sulfide melt. The higher density of the arsenide melts in comparison with sulfide melt further favors this process of sequestering of PGE because arsenide droplets tend to gravitationally settle toward basal regions of the system progressively collecting PGE from the sulfide melt during sinking. The capacity of arsenide melts to dissolve PGE still has not been tested in detail, although several studies show that arsenide and sulfarsenide minerals are excellent carriers of these noble metals. Natural cobaltite can dissolve up to 3.2 wt \% Os, 5.8 wt \% Ir, 3.3 wt \% $\mathrm{Ru}, 31$ wt \% Rh, 1 wt \% Pt, and 5.2 wt \% Pd (Distler and Laputina, 1979; Gervilla et al., 1997, 1998), nickeline up to 8 wt \% Pd and 0.11 wt \% Pt (Cabri, 1992; Watkinson and Ohnenstetter, 1992), and maucherite up to 1.84 wt \% Pd and 0.13 wt \% Pt (Cabri, 1992; Cabri and Laflamme, 1976). Furthermore, experimental studies carried out by Gervilla et al. (1994) in the Pd-Ni-As system reveal that nickeline and maucherite can host up to 5.3 wt \% Pt and 8.6 wt \% Pd at $450^{\circ} \mathrm{C}$. Hence, arsenide melts are able to drastically deplete the coexisting sulfide melt in PGE. 
The timing of formation of the arsenide melt is an important factor controlling the distribution of PGE. If arsenide melts segregate before the crystallization of MSS, the MSS and its exsolution products, pyrrhotite and pentlandite, will be depleted in those PGE typically compatible into the MSS (i.e., Os, Ir, Ru, and Rh, Li et al., 1996; Barnes et al., 1997). The Beni Bousera and Ronda mineralizations (Gervilla and Leblanc, 1990; Leblanc et al., 1990; Gervilla et al., 1996) represent a clear example of this situation where the sulfide ores are strongly depleted in all PGE relative to arsenide ores. In contrast, if As-rich melts form later, after extensive MSS fractionation, the arsenide minerals would be depleted in Os, Ir, $\mathrm{Ru}$, and $\mathrm{Rh}$, since such elements would have been already concentrated into the MSS, becoming only enriched in elements incompatible into MSS, i.e., $\mathrm{Pd}, \mathrm{Pt}, \mathrm{Bi}, \mathrm{Te}, \mathrm{Sb}$, and $\mathrm{Au}$. In fact, this second scenario is generally more common. Arsenic-rich melts generally form after considerable crystallization of MSS. Since the partition coefficients for As, Bi, Te, and $\mathrm{Sb}$ between MSS and sulfide melt are very low (below 0.4, Helmy et al., 2010), these elements progressively enrich into the residual sulfide melt during the fractionation of a typical As-undersaturated sulfide melt. The combination of magma contamination by As-rich rocks and extensive sulfide fractionation can therefore lead to the formation of late-stage As-rich (and $\mathrm{Sb}, \mathrm{Te}, \mathrm{Bi}$ ) melts (also named sulfosalt melts, Tomkins, 2010). Since the incompatible precious metals Pd, $\mathrm{Pt}$, and $\mathrm{Au}$ are progressively concentrated into the residual sulfide melt during MSS fractionation, the late As-rich melts will be typically enriched in these metals. In order to illustrate the importance of timing of arsenide melt segregation on the distribution of PGE, Figure 7 shows mantle-normalized PGE and Au patterns of different As-rich orebodies. The Beni Bousera and Ronda patterns are almost flat, whereas those of Kylmäkoski, Vammala, and Talnotry show a pronounced positive slope from IPGE to $\mathrm{Pt}, \mathrm{Pd}$, and $\mathrm{Au}$, reflecting strong depletion in IPGE relative to PPGE in the arsenide-bearing orebodies. These distribution patterns are thought to be the results of different timing of arsenide melt segregation. Whereas in Beni Bousera and Ronda the separation of arsenide melt took place early, before the formation of MSS, in Kylmäkoski, Vammala, and Talnotry, the arsenide melt segregated from a residual sulfide melt after MSS crystallization. As a consequence, in these deposits, IPGE were previously concentrated into the crystallizing MSS and the residual Asrich sulfide melt became enriched in the most incompatible noble metals, namely Pd, Pt, and $\mathrm{Au}$. Once arsenide melts form, because arsenide melts are significantly denser than sulfide melts, they tend to concentrate by gravitational accumulation in basal regions of magmatic deposits (e.g., Beni Bousera, Gervilla et al., 1996; Kabanga intrusion, Tanzania, Evans et al., 1999). The wetting behavior of arsenide melt against previously solidified sulfide minerals will play an important role in effectively concentrating the arsenide melt. Recently, Tomkins (2010) has demonstrated that As-rich melts containing significant proportions of $\mathrm{Pd}$ and $\mathrm{Pt}$ and exceeding $\sim 0.2 \%$ of the rock volume can wet MSS and percolate downward through an interconnected network. It is thus concluded that the combination of gravitational accumulation and wetting behavior of arsenide melts can drive to the formation of As- and PGE-rich domains within a main sulfide orebody.

Although the results presented here are only applied for As-rich melts, the geologic implications may extrapolate to other semimetals (e.g., Bi and $\mathrm{Te}$ ) that share a similar behavior to As. A number of studies have shown that semimetalsrich liquids can play an important role in governing the PGE partitioning behavior and distribution in magmatic sulfide systems. For example, Helmy et al. (2007) experimentally showed that Te-rich (telluride) melts can separate from a sulfide melt containing high $\mathrm{Te} / \mathrm{S}$ ratios at temperatures ranging $1,015^{\circ}$ to $825^{\circ} \mathrm{C}$, scavenging Pd and Pt. Holwell and McDonald (2010) and Helmy et al. (2010) pointed out that Pt-Pdbearing bismuth or bismuthotelluride minerals located within

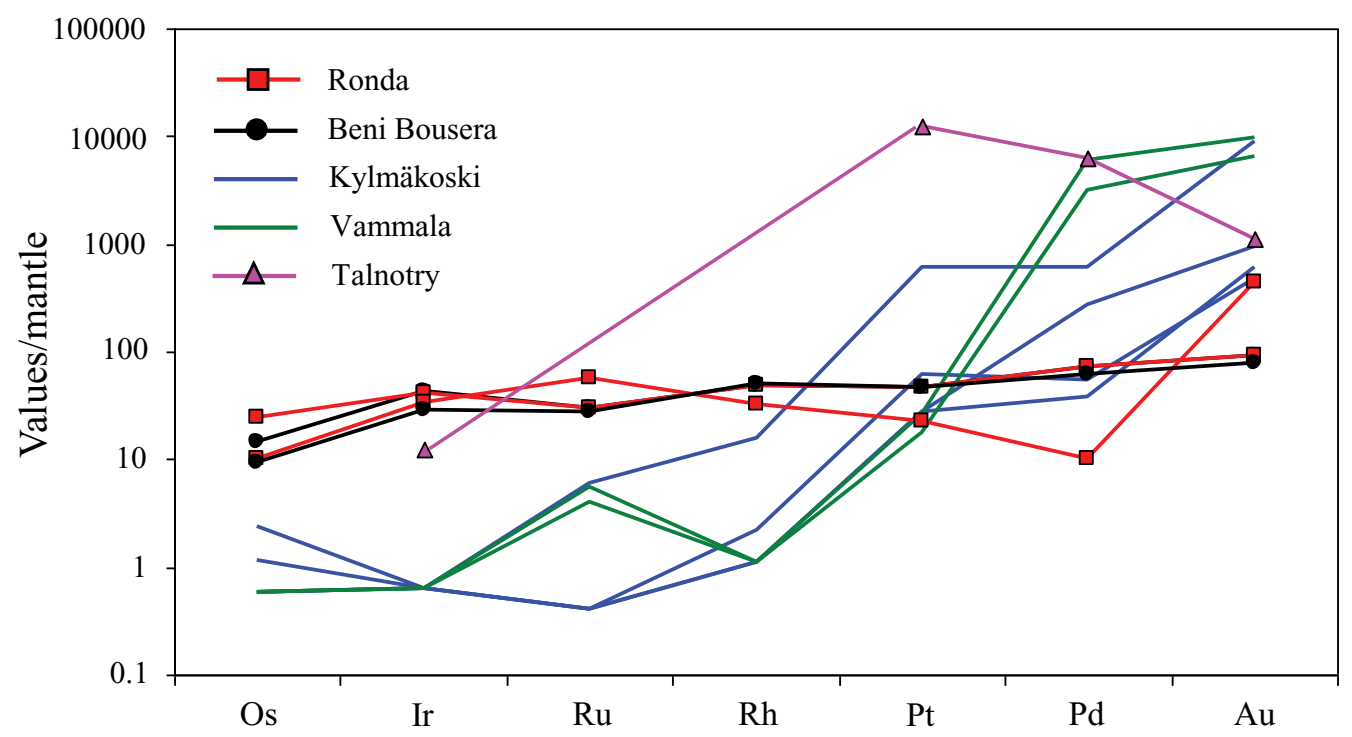

FIG. 7. Whole-rock mantle-normalized patterns for PGE and Au of As-rich orebodies from Beni Bousera, Ronda, Kylmäkoski, Vammala, and Talnotry. Data source for As-rich deposits: Ronda, Gervilla et al. (1996); Kylmäkoski and Vammala, Gervilla et al. (1998); Talnotry, Power et al. (2004). Normalizing values are those of McDonough and Sun (1995). 
or between sulfide grains are the result of crystallization of evolved droplets of Te-Bi-enriched melts (that accommodated the bulk of $\mathrm{Pt}$ and $\mathrm{Pd}$ ) exsolved from late-stage fractionated sulfide melt. The influence of the semimetals on mineralogy and ore composition will strongly depend on the concentration of those elements (Holwell and McDonald, 2010). In this way, when sulfide melt is significantly rich in $\mathrm{Bi}$, $\mathrm{Te}$, and/or Sb (via crustal contamination or another mechanism), Pd and Pt will be preferentially concentrated in the semimetal-rich fractionated melts and strongly depleted in sulfides. Where the concentration of semimetals is low, most $\mathrm{Pd}$ will enter pentlandite and the bulk of Pt will concentrate in the late residual melts, ultimately combining with semimetals to form PGM. Detailed study of the PGE partitioning coefficients between these semimetal-rich melts and sulfide melts will elucidate the behavior of PGE in natural sulfide systems.

\section{Conclusions}

The partition coefficients of PGE and chalcophile elements between arsenide and sulfide phases have been successfully calculated from natural samples coming from the Amasined mineralization in the Beni Bousera massif. Our results indicate that PGE, $\mathrm{Au}, \mathrm{Bi}, \mathrm{Te}$, and $\mathrm{Sb}$ are strongly compatible into arsenides, Re and Ag are only weakly compatible, and Se is moderately incompatible. The obtained values are consistent with the distribution of PGE and chalcophile elements in a number of Ni-Cu-PGE ore deposits containing arsenide-rich zones and underline the potentially important role of arsenide minerals as collectors of these elements. The implications for exploration are considerable: the formation of arsenide melts can lead to the formation of As-PGE-rich horizons or lenses associated with S-rich and PGE-poor mineralized zones in magmatic sulfide deposits. A number of factors such as initial PGE content of sulfide melt, timing of arsenide segregation/crystallization, and efficient concentration of AsPGE-bearing melt will influence the formation of an economic PGE- and As-rich deposit.

\section{Acknowledgments}

The authors are very grateful to Dany Savard for his assistance with the laser ablation analysis, and José González de Tánago and Alfredo Larios who kindly assisted in the electron microprobe analysis. Constructive comments from Steve Barnes, Jacob Hanley, and Hassan Helmy on earlier versions of this manuscript are greatly appreciated and we thank Sarah Dare and Raúl Merinero for discussions about analytical work. We very much appreciate the reviews from David Holwell and Bèlinda Godel, Associate editor Steve Barnes, and Editor Larry Meinert, who significantly improved the manuscript. This research was financed by the Spanish research project CGL2007-60266 and the Canada Research Chair in Magmatic Metallogeny. Rubén Piña’s stay at UQAC was financed with a "José Castillejo" travel aid financed by Spanish Ministry of Science.

\section{REFERENCES}

Barnes, S.-J., Makovicky, E., Karup-Moller, S., Makovicky, M., and RoseHanson, J., 1997, Partition coefficients for Ni, Cu, Pd, Pt, Rh and $\mathrm{Ir}$ between monosulfide solid solution and sulphide liquid and the implications for the formation of compositionally zoned Ni-Cu sulphide bodies by fractional crystallization of sulphide liquid: Canadian Journal of Earth Science, v. 34, p. 366-374.

Barnes, S.-J., Cox, R.A., and Zientek, M.L., 2006, Platinum-group element, gold, silver and base metal distribution in compositionally zoned sulfide droplets from the Medvezky Creek mine, Noril'sk, Russia: Contributions to Mineralogy and Petrology, v. 152, p. 187-200.

Cabri, L.J., 1992, The distribution of trace precious metals in minerals and mineral products: Mineralogical Magazine, v. 56, p. 289-308.

Cabri, L.J., and Laflamme, J.H.G., 1976, The mineralogy of the platinumgroup elements from some copper-nickel deposits of the Sudbury area, Ontario: ECONOMIC GEOLOGY, v. 71, p. 1159-1195.

Crespo, E., Luque, F.J., Rodas, M., Wada, H., and Gervilla, F., 2006, Graphite-sulfide deposits in Ronda and Beni Bousera peridotites (Spain and Morocco) and the origin of carbon in mantle-derived rocks: Gondwana Research, v. 9, p. 279-290.

Crocket, J.H., Fleet, M.E., and Stone, W.E., 1992, Experimental partitioning of osmium, iridium, and gold between basalt melt and sulfide liquid at $1300^{\circ} \mathrm{C}$ : Australian Journal of Earth Science, v. 39, p. 427-432.

Czamanske, G.K., and Moore, J.G., 1977, Composition and phase chemistry of sulfide globules in basalt from the Mid-Atlantic Ridge rift valley near $37^{\circ} \mathrm{N}$ lat: Geological Society of American Bulletin, v. 88, p. 587-599.

Dare, S.A.S., Barnes, S.-J., and Prichard, H.M., 2010, The distribution of platinum group elements and other chalcophile elements among sulfides from the Creighton Ni-Cu-PGE sulfide deposit, Sudbury, Canada, and the origin of Pd in pentlandite: Mineralium Deposita, v. 45, p. 765-793.

Distler, V.V., and Laputina, I.L., 1979, Nickel and cobalt sulpharsenides containing platinum metals: Doklady Akademii Nauk, v. 24, p. 718-721.

Evans, D.M., Byemelwa, L., and Gilligan, J., 1999, Variability of magmatic sulphide compositions at the Kabanga nickel prospect, Tanzania: Journal of African Earth Science, v. 29, p. 329-351.

Fleet, M.E., Stone, W.E., and Crocket, J.H., 1991, Partitioning of palladium, iridium, and platinum between sulfide liquid and basalt melt: Effects of melt composition concentration and oxygen fugacity: Geochimica et Cosmochimica Acta, v. 55, p. 2545-2554.

Fleet, M.E., Chryssoulis, S.L., Stone, E.S., and Weisener, C. G., 1993, Partitioning of platinum-group elements and $\mathrm{Au}$ in the $\mathrm{Fe}-\mathrm{Ni}-\mathrm{Cu}-\mathrm{S}$ system: Experiments on the fractional crystallization of sulfide melt: Contributions to Mineralogy and Petrology, v. 115, p. 36-44.

Gervilla, F., and Leblanc, M., 1990, Magmatic ores in high-temperature alpine-type lherzolite massifs (Ronda, Spain, and Beni Bousera, Morocco): ECONOMIC GEOLOGY, v. 85, p. 112-132.

Gervilla, F., Makovicky, E., Makovicky, M., and Rose-Hansen, J., 1994, The system Pd-Ni-As at $790^{\circ}$ and $450^{\circ} \mathrm{C}$ : ECONOMIC Geology, v. 89, p. $1630-1639$.

Gervilla, F., Leblanc, M., Torres-Ruiz, J., and Fenoll Hach-Alí, P., 1996, Immiscibility between arsenide and sulfide melts: a mechanism for the concentration of noble metals: Canadian Mineralogist, v. 34, p. 485-502.

Gervilla, F., Sánchez-Anguita, A., Acevedo, R., Fenoll Hach-Alí, P., and Paniagua, A., 1997, Platinum-group element sulpharsenides and Pd bismuthotellurides in the metamorphosed $\mathrm{Ni}-\mathrm{Cu}$ deposit at Las Aguilas (Province of San Luis, Argentine): Mineralogical Magazine, v. 61, p. 861-877.

Gervilla, F., Papunen, H., Kojonen, K., and Johanson, B., 1998, Platinum-, palladium- and gold-rich arsenide ores from the Kylmäkoski Ni-Cu deposit (Vammala nickel belt, SW Finland): Mineralogy and Petrology, v. 64, p. $163-185$.

Gervilla, F., Gutiérrez-Narbona, R., and Fenoll-Hach-Alí, P., 2002, The origin of different types of magmatic mineralizations from small-volume melts in the lherzolite massifs of the Serranía de Ronda: Boletín de la Sociedad Española de Mineralogía, v. 25, p. 79-96.

Gervilla, F., Cabri, L.J., Kojonen, K., Oberthur, T., Weiser, T.W., Johanson, B., Sies, S.H.S., Campbell, J.L., Teesdale, W.J., and Laflamme, G., 2004, Platinum-group element distribution in some ore deposits: Results of EPMA and micro-PIXE analyses: Microchimica Acta, v. 147, p. 167-173.

Godel, B., Barnes, S.-J., and Maier, W.D., 2007, Platinum-group elements in sulphide minerals, platinum-group minerals, and whole-rocks of the Merensky Reef (Bushveld Complex, South Africa): Implications for the formation of the Reef: Journal of Petrology, v. 48, p. 1569-1604.

Godel, B., González-Álvarez, I., Barnes, S.J., Barnes, S.-J., Parker, P., and Day, J., 2012, Sulfides and sulfarsenides from the Rosie nickel prospect, Duketon greenstone belt, Western Australia: ECONOMIC GEOLOGY, v. 107, p. $275-294$. 
Hanley, J.J., 2007, The role of arsenic-rich melts and mineral phases in the development of high-grade Pt-Pd mineralization within komatiite-associated magmatic Ni-Cu sulfide horizons at Dundonald Beach South, Abitibi subprovince, Ontario, Canada: ECONOMIC GEOLOGY, v. 102, p. 305-317.

Hattori, K., Arai, S., and Clarke, D.B., 2002, Selenium, tellurium, arsenic and antimony contents of primary mantle sulfides: Canadian Mineralogist, v. 40 , p. $637-650$.

Helmy, H.M., Ballhaus, C., Berndt, J., Bockrath, C., and Wohlgemuth-Ueewasser, C., 2007, Formation of Pt, Pd and Ni tellurides: Experiments in sulphide-telluride systems: Contributions to Mineralogy and Petrology, v. 153, p. 577-591.

Helmy, H.M., Ballhaus, C., Wohlgemuth-Ueewasser, C., Fonseca, R., and Laurenz, V., 2010, Partitioning of Se, As, Sb, Te and Bi between monosulfide solid solution and sulfide melt-application to magmatic sulfide deposits: Geochimica et Cosmochimica Acta, v. 74, p. 6174-6179.

Holwell, D.A., and McDonald, I., 2007, Distribution of platinum-group elements in the Platreef at Overysel, northern Bushveld Complex: A combined PGM and LA-ICP-MS study: Contributions to Mineralogy and Petrology, v. 154, p. 171-190.

2010, A review of the behaviour of platinum group elements within natural magmatic sulfide ore systems: Platinum Metals Review, v. 54, p. $26-36$.

Huminicki, M.A.E., Sylvester, P.J., Cabri, L.J., Lesher, C.M., and Tubrett, M., 2005, Quantitative mass balance of platinum group elements in the Kelly Lake Ni-Cu-PGE deposit, Copper Cliff offset, Sudbury: Economic GEOLOGY, v. 100, p. 1631-1646.

Hutchinson, D., and McDonald, I., 2008, Laser ablation ICP-MS study of platinum-group elements in sulphides from the Platreef at Turfspruit, northern limb of the Bushveld Complex, South Africa: Mineralium Deposita, v. 43, p. 695-711.

Ishimaru, S., and Arai, S., 2008, Arsenide in a metasomatized peridotite xenolith as a constraint on arsenic behavior in the mantle wedge: American Mineralogist, v. 93, p. 1061-1065.

Leblanc, M., Gervilla, F., and Jedwab, J., 1990, Noble metals segregation and fractionation in magmatic ores from Ronda and Beni Bousera lherzolite massifs (Spain, Morocco): Mineralogy and Petrology, v. 42, p. 233-248.

Lenoir, X., Garrido, C.J., Bodinier, J-L., Dautria, J-M., and Gervilla, F., 2001, The recrystallization front of the Ronda Peridotite: Evidence for melting and thermal erosion of subcontinental lithosperic mantle beneath the Alborán basin: Journal of Petrology, v. 42, p. 141-158.

Li, C., Barnes, S.-J., Makovicky, E., Rose-Hansen, J., and Makovicky, M., 1996, Partitioning of nickel, copper, iridium, rhenium, platinum, and palladium between monosulfide solid solution and sulfide liquid: Effects of composition and temperature: Geochimica et Cosmochimica Acta, v. 60, p. $1231-1238$.

Lorand, J.P., 1987, Sur l'origine mantlellaire de l'arsenic dans les rockes du manteau: exemple des pyroxénites à grenat du massif lherzolitique des Beni Bousera (Rif, Maroc): Les Comptes Rendus de l'Académie des Sciences Paris, v. 305, p. 383-386.

Makovicky, E., Karup-Moller, S., Makovicky, M., and Rose-Hansen, J., 1990, Experimental studies on the phase systems Fe-Ni-Pd-S and Fe-Pt-Pd-As-S applied to PGE deposits: Mineralogy and Petrology, v. 42, p. 307-319.

Makovicky, M., Makovicky, E., and Rose-Hansen, J., 1992, The phase system Fe-Pt-As-S at $850^{\circ} \mathrm{C}$ and $470^{\circ} \mathrm{C}$ : Neues Jahrbuch für Mineralogie, v. 10, p. 441-453.

McDonough, W.F., and Sun, S.S., 1995, The composition of the Earth: Chemical Geology, v. 120, p. 223-253.

Michard, A., Negro, F., Saddiqi, O., Bouybaouene, M.L., Chalouan, A., Montigny, R., and Goffé, B., 2006, Pressure-temperature-time constraints on the Maghrebide mountain building: Evidence from the Rif-Betic transect (Morocco, Spain), Algerian correlations, and geodynamic implications: C.R. Science, v. 338, p. 92-114.
Naldrett, A.J., 2004, Magmatic sulfide deposits: Geology, geochemistry and exploration: New York, Springer Berlin Heidelberg, $727 \mathrm{p}$.

Papunen, H., 1989, Platinum-group elements in metamorphosed $\mathrm{Ni}-\mathrm{Cu}$ deposits in Finland, in Prendergast, M.J., and Jones, M.J., eds., Magmatic sulfides, the Zimbabwe volume: Institution of Mining and Metallurgy, p. $165-176$.

Paton, C., Hellstrom, J., Paul, B., Woodhead, J., and Hergt, J., 2011, Iolite: Freeware for the visualization and processing of mass spectrometric data: Journal of Analytical Atomic Spectrometry, v. 26, p. 2508-2518.

Peach, C.L., Mathez, E.A., and Keays, R.R., 1990, Sulfide melt-silicate melt distribution coefficience for noble metals and other chalcophile elements as deduced from MORB: Implications for partial melting: Geochimica et Cosmochimica Acta, v. 54, p. 3379-3389.

Power, M.R., Pirrie, D., Jedwab, J., and Stanley, C.J., 2004, Platinum-group element mineralization in an As-rich magmatic sulfide system, Talnotry, southwest Scotland: Mineralogical Magazine, v. 68, p. 395-411.

Reuber, I., Michard, A., Chalouan, A., Juteau, T.A., and Jermoumi, B., 1982, Structures and emplacement of the alpine-type peridotites from Beni Bousera, Rif, Morocco: A polyphase tectonic interpretation: Tectonophysics, v. 82, p. 231-254.

Thériault, R., and Barnes, S.-J., 1998, Compositional variations in $\mathrm{Cu}-\mathrm{Ni}$ PGE sulfides of the Dunka Road deposit, Duluth Complex, Minnesota: the importance of combined assimilation and magmatic processes: Canadian Mineralogist, v. 36, p. 869-886.

Tomkins, A.G., 2010, Wetting facilitates late-stage segregation of precious metal-enriched sulfosalt melt in magmatic sulfide systems: Geology, v. 38, p. $951-954$.

Torres-Ruíz, J., Gervilla, F., and Leblanc, M., 1991, Mineralogía y comportamiento geoquímico del oro en los macizos lherzolíticos Bético-Rifeños (España-Marruecos): Estudios Geológicos, v. 47, p. 281-293.

Tubia, J.M., and Cuevas, J., 1986, High-temperature emplacements of Los Reales peridotite nappe (Betic Cordillera, Spain): Journal of Structural Geology, v. 8, p. 473-482.

Van der Wal, D., and Bodinier, J.L., 1996, Origin of the recrystallization front in the Ronda peridotite by $\mathrm{km}$-scale pervasive porous melt flow: Contributions to Mineralogy and Petrology, v. 122, p. 387-405.

Watkinson, D.H., and Ohnenstetter, D., 1992, Hydrothermal origin of platinum-group mineralization in the Two-Duck Lake intrusion, Coldwell Complex, northwestern Ontario: Canadian Mineralogist, v. 30, p. 121-136.

Wilson, S.A., Ridley, W.I., and Koenig, A.E., 2002, Development of sulfide calibration standards for laser ablation inductively-coupled mass spectrometry technique: Journal of Analytical Atomic Spectrometry, v. 17, p. 406-409.

Wood, M., 2003, Arsenic in igneous systems: An experimental investigation: Unpublished B.A. Sc. thesis, Toronto, Canada, University of Toronto, $32 \mathrm{p}$. Yund, R.A., 1961, Phase relations in the system Ni-As: Economic Geology, v. 56, p. 1273-1296.

Zientek, M.L., Likhachev, A.P., Kunilov, V.E., Barnes, S.J., Meier, A.L., Carlson, R.R., Briggs, P.H., Fries, T.L., and Adrian, B.M., 1994, Cumulus processes and the composition of magmatic ore deposits: Examples from the Talnakh district, Russia: Ontario Geological Survey Special Publication 5, p. 373-392.

Zindler, A., Staudiel, M., Hart, S.R., Enders, R., and Goldstein, S., 1983, Nd and $\mathrm{Sr}$ isotope study of a mafic layer from Ronda ultramafic complex: Nature, v. 304, p. 226-230. 
TABLE A1. Values for Reference Materials Used in the Calibration of LA-ICP-MS

\begin{tabular}{|c|c|c|c|c|c|c|c|c|c|c|}
\hline Isotope & & $\begin{array}{l}34 \mathrm{~S} \\
(\%)\end{array}$ & $\begin{array}{c}57 \mathrm{Fe} \\
(\%)\end{array}$ & $\begin{array}{c}61 \mathrm{Ni} \\
(\%)\end{array}$ & $\begin{array}{c}65 \mathrm{Cu} \\
(\%)\end{array}$ & $\begin{array}{c}68 \mathrm{Zn} \\
((\mathrm{ppm}))\end{array}$ & $\begin{array}{l}\text { 75As } \\
(\mathrm{ppm})\end{array}$ & $\begin{array}{c}82 \mathrm{Se} \\
(\mathrm{ppm})\end{array}$ & $\begin{array}{l}\text { 101Ru } \\
(\mathrm{ppm})\end{array}$ & $\begin{array}{l}\text { 103Rh } \\
\text { (ppm) }\end{array}$ \\
\hline \multicolumn{11}{|c|}{$\underline{\text { Reference materials used for calibration of sulfide minerals }}$} \\
\hline & $\begin{array}{l}\text { Working values } \\
\text { S.D } \\
\text { Based on }\end{array}$ & $\begin{array}{c}\text { po- } 727 \\
39 \\
0.4 \\
\text { Certif. }\end{array}$ & $\begin{array}{c}\text { po- } 727 \\
61.1 \\
0.2 \\
\text { Certif. }\end{array}$ & & $\begin{array}{c}\text { mass-1 } \\
13.4 \\
\text { n.d. } \\
\text { W } 2002\end{array}$ & $\begin{array}{c}\text { mass-1 } \\
210000 \\
\text { n.d. } \\
\text { W } 2002\end{array}$ & $\begin{array}{c}\text { mass-1 } \\
65 \\
\text { n.d. } \\
\text { W } 2002\end{array}$ & $\begin{array}{c}\text { mass-1 } \\
53 \\
\text { n.d. } \\
\text { W } 2002\end{array}$ & $\begin{array}{c}\text { po- } 727 \\
36.3 \\
0.3 \\
\text { Certif. }\end{array}$ & $\begin{array}{c}\text { po-727 } \\
41.4 \\
0.3 \\
\text { Certif. }\end{array}$ \\
\hline
\end{tabular}

Values obtained for in-house reference materials

UQAC-MSS1, $\mathrm{NiFeS}_{2}$

$\begin{array}{llcc} & \text { Working } & & \\ & \text { values } & 38.00 & 30.30 \\ & \text { S.D. } & 0.50 & 1.30 \\ \text { This study } & \text { Based on } & \text { EMP } & \text { EMP } \\ n=36 & \text { Average } & 37.42 & \text { Int std } \\ & \text { S.D. } & 4.34 & \\ & \text { Rel. diff. } & 0.98 & \end{array}$

$\begin{array}{cccccc}0.003 & 58.8 & 1.90 & 5.30 & 1.75 & 0.94 \\ 0.001 & 20.3 & 0.21 & 0.35 & 0.03 & 0.01 \\ \text { Nist610 } & \text { Nist611 } & \text { Nist610 } & \text { Nist610 } & \text { ID-sol } & \text { ID-sol } \\ 0.003 & 20.3 & 56.71 & 5.22 & 2.42 & 0.91 \\ 0.001 & 14.4 & 48.40 & 0.79 & 0.18 & 0.05 \\ 1.07 & 0.34 & 29.85 & 0.98 & 1.38 & 0.97\end{array}$

JBMSS5, FeS

\section{Working}

$\begin{array}{lll}\text { values } & 40 & 57\end{array}$

S.D. $\quad 0.60 \quad 0.90$

Based on po727 po727

This study Average $\quad 39.14 \quad$ Int std

$n=44$$$
4.51
$$

Rel. diff.

0.98

0.021
0.001
LA
0.025
0.01
1.19


jbmss5

0.021
0.001

$<10$
Nist610
34.1
17.7

79.0
11.0
ICP-sol
119.6
67.4
1.51

48.4
14.80
Nist610
58.03
6.51

$\begin{array}{cc}21.70 & 61.40 \\ & 7.20 \\ \text { ID-sol } & \text { ICP-sol } \\ 21.56 & 60.27 \\ 1.15 & 3.11 \\ 0.99 & 0.98\end{array}$

$\underline{\text { Reference material used for calibration of maucherites }}$

\begin{tabular}{|c|c|c|c|c|c|c|c|}
\hline & jbmss 5 & jbmss5 & jbmss5 & jbmss5 & jbmss5 & jbmss5 & jbmss5 \\
\hline $\begin{array}{l}\text { Working } \\
\text { values }\end{array}$ & 40 & 57 & 1.05 & 0.021 & 48.4 & 21.70 & 61.40 \\
\hline S.D. & 0.60 & 0.90 & n.d. & 0.001 & 14.80 & & 7.20 \\
\hline
\end{tabular}

$\underline{\text { Values obtained for in-house reference materials }}$

\section{UQAC-MSS1, $\mathrm{NiFeS}_{2}$

$$
\text { Working }
$$ \\ values}

S.D.

This study

$n=19$

\begin{abstract}
Average
S.D.
\end{abstract}

Rel. diff.

$\begin{array}{cc}38.00 & 30.30 \\ 0.50 & 1.30 \\ 40.35 & 30.60 \\ 0.21 & 1.22 \\ 1.06 & 1.01\end{array}$

$\begin{array}{cc}31.00 & 0.003 \\ 7.00 & 0.001 \\ & \\ \text { Int std } & 0.002 \\ & 0.000 \\ & 0.80\end{array}$

$\begin{array}{lll}5.30 & 1.75 & 0.94 \\ 0.35 & 0.03 & 0.01 \\ & & \\ 4.06 & 2.50 & 0.94 \\ 0.06 & 0.01 & 0.08 \\ 0.77 & 1.43 & 1.00\end{array}$

Notes: Po-727 is a certified synthetic FeS supplied by the Memorial University of Newfoundland; Mass-1 is an FeCuZnS pressed powder pellet supplied by USGS; Jbmss 5 is a synthetic FeS in-house reference material supplied by J. Brenan from the University of Toronto; UQAC-MSS1 is a synthetic NiFeS 2 supplied by A. Peregoedova; Certif.= values certified obtained by solution ICP-MS, W 2002 = values published in Wilson et al. (2002), Nist610 = laser ablation using Nist610 for calibration, SQ-Nist610 = semiquantification using Nist610 for calibration, ID-sol = solution by isotopic dilution followed by ICP-MS, ICP-sol = solution by aqua regia followed by ICP-MS. AA = solution by aqua regia followed by atomic absorption. LA = laser ablation ICP-MS. EMP = electron microprobe. S.D. = standard deviation; n.d. = not determined; int std = internal standard; $n=$ number of analyses, Rel. diff. $=$ relative difference of this study/working value 
and Analyses of In-House Reference Materials for Monitoring the Data Quality

\begin{tabular}{|c|c|c|c|c|c|c|c|c|c|c|}
\hline $\begin{array}{l}105 \mathrm{Pd} \\
(\mathrm{ppm})\end{array}$ & $\begin{array}{l}107 \mathrm{Ag} \\
(\mathrm{ppm})\end{array}$ & $\begin{array}{l}111 \mathrm{Cd} \\
(\mathrm{ppm})\end{array}$ & $\begin{array}{l}121 \mathrm{Sb} \\
(\mathrm{ppm})\end{array}$ & $\begin{array}{l}125 \mathrm{Te} \\
(\mathrm{ppm})\end{array}$ & $\begin{array}{l}\text { 187Re } \\
(\mathrm{ppm})\end{array}$ & $\begin{array}{l}\text { 189Os } \\
(\mathrm{ppm})\end{array}$ & $\begin{array}{l}193 \mathrm{Ir} \\
(\mathrm{ppm})\end{array}$ & $\begin{array}{l}195 \mathrm{Pt} \\
(\mathrm{ppm})\end{array}$ & $\begin{array}{l}197 \mathrm{Au} \\
(\mathrm{ppm})\end{array}$ & $\begin{array}{l}209 \mathrm{Bi} \\
(\mathrm{ppm})\end{array}$ \\
\hline $\begin{array}{c}\text { po- } 727 \\
43.1 \\
0.4 \\
\text { Certif. }\end{array}$ & $\begin{array}{c}\text { mass-1 } \\
67 \\
\text { n.d. } \\
\text { W } 2002\end{array}$ & $\begin{array}{c}\text { mass-1 } \\
70 \\
\text { n.d. } \\
\text { W } 2002\end{array}$ & $\begin{array}{c}\text { mass-1 } \\
55 \\
\text { n.d. } \\
\text { W } 2002\end{array}$ & $\begin{array}{c}\text { mass-1 } \\
33 \\
0.7 \\
\text { SQ-Nist610 }\end{array}$ & $\begin{array}{c}\text { jbmss.5 } \\
20.7 \\
\text { n.d. } \\
\text { ID-sol }\end{array}$ & $\begin{array}{c}\text { po- } 727 \\
46.9 \\
2.5 \\
\text { Certif. }\end{array}$ & $\begin{array}{c}\text { po-727 } \\
47.8 \\
1.2 \\
\text { Certif. }\end{array}$ & $\begin{array}{c}\text { po- } 727 \\
35.4 \\
0.8 \\
\text { Certif. }\end{array}$ & $\begin{array}{c}\text { po-727 } \\
45.8 \\
2.3 \\
\text { Certif. }\end{array}$ & $\begin{array}{c}\text { mass-1 } \\
66 \\
0.9 \\
\text { Nist610 }\end{array}$ \\
\hline $\begin{array}{c}1.26 \\
0.05 \\
\text { ID-sol } \\
1.13 \\
0.10 \\
0.90\end{array}$ & $\begin{array}{c}0.27 \\
0.08 \\
\text { Nist610 } \\
0.14 \\
0.05 \\
0.52\end{array}$ & $\begin{array}{c}0.27 \\
0.06 \\
\text { Nist610 } \\
0.11 \\
0.08 \\
0.41\end{array}$ & $\begin{array}{c}0.08 \\
0.03 \\
\text { Nist610 } \\
0.18 \\
0.12 \\
2.25\end{array}$ & $\begin{array}{c}0.29 \\
0.22 \\
\text { SQ-Nist610 } \\
0.26 \\
0.13 \\
0.90\end{array}$ & $\begin{array}{c}0.09 \\
0.001 \\
\text { ID-sol } \\
0.11 \\
0.002 \\
1.17\end{array}$ & $\begin{array}{c}1.90 \\
0.01 \\
\text { ID-sol } \\
1.51 \\
0.13 \\
0.79\end{array}$ & $\begin{array}{c}1.37 \\
0.01 \\
\text { ID-sol } \\
1.34 \\
0.10 \\
0.98\end{array}$ & $\begin{array}{c}1.66 \\
0.01 \\
\text { ID-sol } \\
1.36 \\
0.13 \\
0.82\end{array}$ & $\begin{array}{c}1.21 \\
0.24 \\
\text { Nist610 } \\
1.20 \\
0.17 \\
0.99\end{array}$ & $\begin{array}{c}<0.02 \\
\text { Nist610 } \\
0.07 \\
0.05\end{array}$ \\
\hline $\begin{array}{c}64.10 \\
\text { ID-sol } \\
55.00 \\
2.53 \\
0.86\end{array}$ & $\begin{array}{c}60.70 \\
3.70 \\
\text { ICP-sol } \\
59.68 \\
3.57 \\
0.98\end{array}$ & $\begin{array}{c}0.13 \\
0.04 \\
\text { Nist610 } \\
0.45 \\
0.33 \\
3.46\end{array}$ & $\begin{array}{c}61.30 \\
7.30 \\
\text { ICP-sol } \\
49.11 \\
4.51 \\
0.80\end{array}$ & $\begin{array}{c}67.00 \\
9.00 \\
\text { SQ-Nist610 } \\
41.61 \\
5.45 \\
0.62\end{array}$ & & $\begin{array}{c}42.60 \\
0.93 \\
\text { ICP-sol } \\
58.63 \\
7.06 \\
1.38\end{array}$ & $\begin{array}{c}44.00 \\
\text { ID-sol } \\
42.20 \\
3.23 \\
0.96\end{array}$ & $\begin{array}{c}47.00 \\
\text { ID-sol } \\
40.31 \\
1.55 \\
0.86\end{array}$ & $\begin{array}{c}35.90 \\
4.80 \\
\text { ICP-sol } \\
37.18 \\
2.19 \\
1.04\end{array}$ & $\begin{array}{c}76.10 \\
2.9 \\
\text { ICP-sol } \\
76.10 \\
5.85 \\
1.00\end{array}$ \\
\hline jbmss5 & jbmss5 & jbmss5 & jbmss5 & jbmss5 & jbmss5 & jbmss5 & jbmss5 & jbmss5 & jbmss5 & jbmss5 \\
\hline 64.10 & $\begin{array}{c}60.70 \\
3.70\end{array}$ & $\begin{array}{l}0.13 \\
0.04\end{array}$ & $\begin{array}{c}61.30 \\
7.30\end{array}$ & $\begin{array}{c}67.00 \\
9.00\end{array}$ & $\begin{array}{l}20.7 \\
\text { n.d. }\end{array}$ & $\begin{array}{c}42.60 \\
0.93\end{array}$ & 44.00 & 47.00 & $\begin{array}{c}35.90 \\
4.80\end{array}$ & $\begin{array}{c}76.10 \\
2.9\end{array}$ \\
\hline $\begin{array}{l}1.26 \\
0.05\end{array}$ & $\begin{array}{l}0.27 \\
0.08\end{array}$ & $\begin{array}{l}0.27 \\
0.06\end{array}$ & $\begin{array}{l}0.08 \\
0.03\end{array}$ & $\begin{array}{l}0.29 \\
0.22\end{array}$ & $\begin{array}{c}0.09 \\
0.001\end{array}$ & $\begin{array}{l}1.90 \\
0.01\end{array}$ & $\begin{array}{l}1.37 \\
0.01\end{array}$ & $\begin{array}{l}1.66 \\
0.01\end{array}$ & $\begin{array}{l}1.21 \\
0.24\end{array}$ & $<0.02$ \\
\hline $\begin{array}{l}1.37 \\
0.09 \\
1.09\end{array}$ & $\begin{array}{l}0.11 \\
0.01 \\
0.41\end{array}$ & $\begin{array}{l}0.04 \\
0.03 \\
0.15\end{array}$ & $\begin{array}{l}0.21 \\
0.05 \\
2.63\end{array}$ & $\begin{array}{l}0.28 \\
0.03 \\
0.97\end{array}$ & $\begin{array}{c}0.11 \\
0.002 \\
1.17\end{array}$ & $\begin{array}{l}1.14 \\
0.19 \\
0.60\end{array}$ & $\begin{array}{l}1.31 \\
0.19 \\
0.96\end{array}$ & $\begin{array}{l}1.38 \\
0.12 \\
0.83\end{array}$ & $\begin{array}{l}1.16 \\
0.14 \\
0.96\end{array}$ & $\begin{array}{l}0.05 \\
0.01\end{array}$ \\
\hline
\end{tabular}




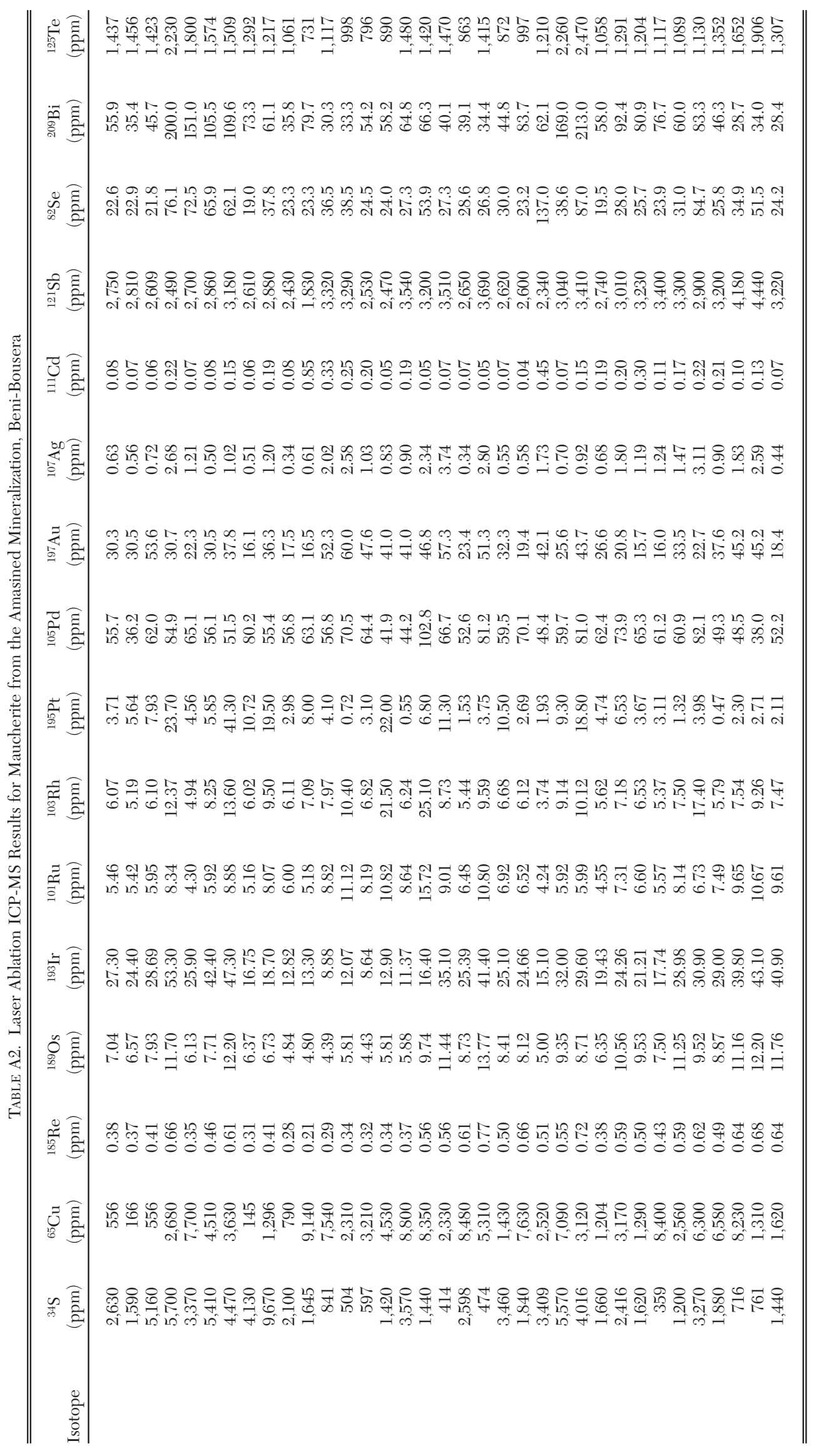




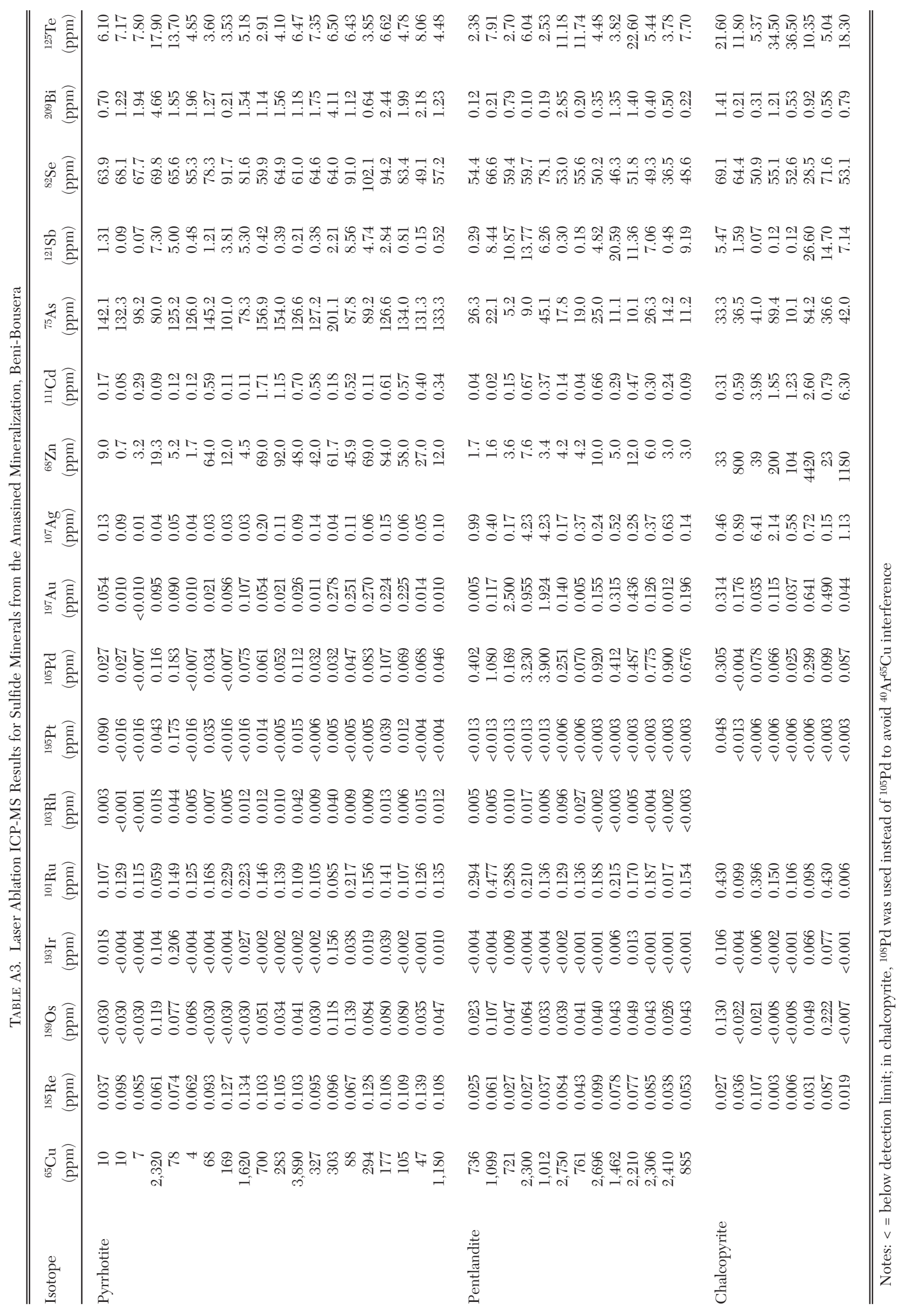

